Report of Investigations 2001-1B

\title{
GEOLOGIC MAP OF THE CHULITNA REGION, SOUTHCENTRAL ALASKA
}

\author{
by \\ K.H. Claunice, R.J. Newberry, D.S. Pinney, R.B. Blodgen, \\ T.K. Bundzen, B.G. Gage, E.E. Hams, S.A. Liss, \\ M.L. Miller, R.R. Reifenstuhl, and J.G Clough
}

2001

This DGGS Report of Investigations is a final repon of scientific research. It has received technical review and may be cited as an agency publication.

Research supported in part by the U.S. Geological Survey, National Cooperative Geologic Mapping Program, under USGS award nunber 98HQAG2083. The views and conclusions contained in this document are those of the aushors and should not be interpreted as necessarily representing the official policies, either expressed or inuplied, of the U.S. Government. 


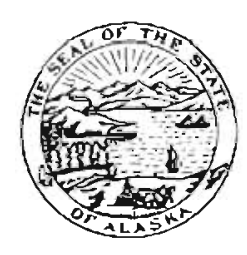

STATE OF ALASKA

Tony Knowles, Governor.

DEPARTMENT OF NATURAL RESOURCES

Pat Pourchot, Commissioner

DIVISION OF GEOLOGICAL \& GEOPHYSICAL SURVEYS

Milion A. Wiltse. Director and Srare Geologisı

Division of Geological \& Geophysical Surveys publications can be inspected at the following locations. Address mail orders to the Fairbanks office.

Alaska Division of Geological

\& Geophysical Surveys

794 University A venue, Suice 200

Fairbanks, Alaská 99709-3645

Elmer E. Rasmuson Library

University of A laska Fairbanks

Fairbanks. Alaska 99775-1005
University of Alaska Anchorage Library 321 I Providence Drive

Anchorage. Alaska 99508

Alaska Resource Library

3150 C Sireet. Suite 100

Anchorage, Alasks 99503

Alaska Stale Library

State Office Building. 8th Floor

333 Willoughby Avenue

Juneuu, A laska $99811-0571$

This publication released by the Division of Geological \& Geophysical Surveys was produced and printed in Fairbanks, Alaska at a cost of $\$ 16$ per copy. Publication is required by Alaska Statute 41, "to determine the potential of Alaskan land for production of metals, minerals, fucls, and geothermal resources; the location and supplies of groundwater and construction materials: the potentál geologic hazards to buiddings, roads, bridges, and other installations and structures: and shall conduct such other surveys and investigations as will advance knowledge of the geology of Alaska." 


\section{CONTENTS}

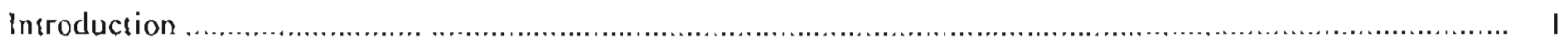

Previous work

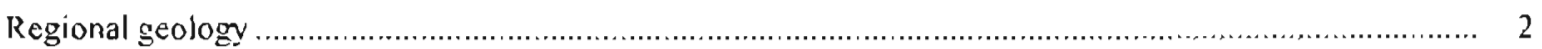

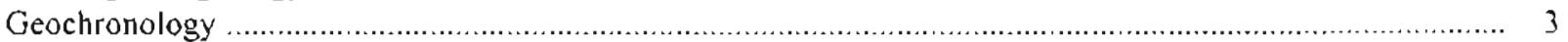

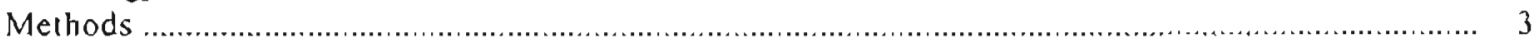

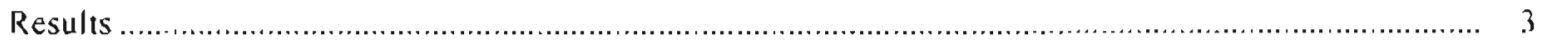

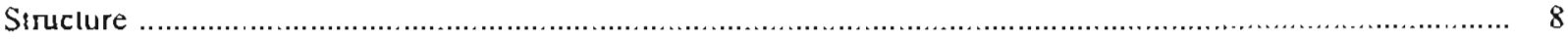

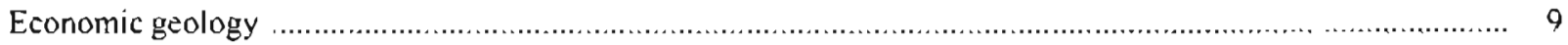

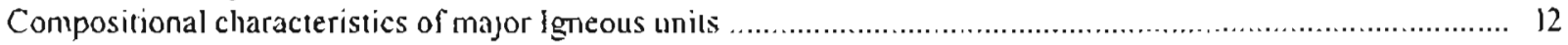

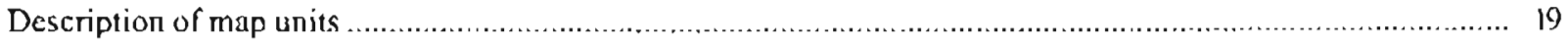

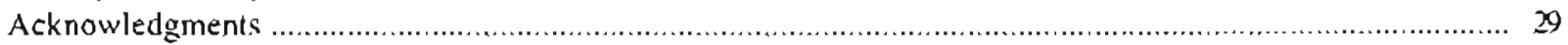

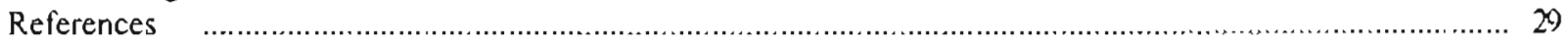

\section{FIGURES}

Figure I. Chulitna area location map showing selected mineral deposits and prospectsand boundaries of airbome geophysical survey and geologic mapping ......................................... I

2. Diagram illustrating suggested stratigraphic and igneous linkages between Chulitna, Peninsular, and Wrangellia terranes

3. Simplified structural map of the Chulitna district, showing interpreted high-angle

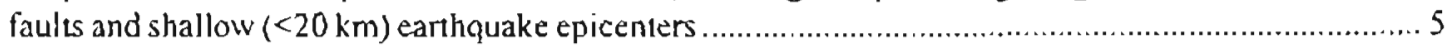

4. Photo showing the Goiden Zone Mine mill ........................................................................

5. Photo showing the confact between the ore body breccia and the scrongly jointed Cretaceous monzonite, at the Golden Zone Mine ................................................................... 9

6. Diagram illustrating concentrations of silver vs. gold in mineralized samples from the Chulitma area .... 10

7. Diagram illustrating interpreted ${ }^{31} \mathrm{~A} r \mathrm{r}^{\prime 3)} \mathrm{Ar}$ ages for mineralized and related rocks ............................ 11

\&. Diagram illustrating rock rype classification ................................................................. 14

9. Diagram illustraling major element compositions of red clastic rocks ........................................ 15

10. Diagram illustrating tectonic classification of Chulitna arca mafic-composition igneous

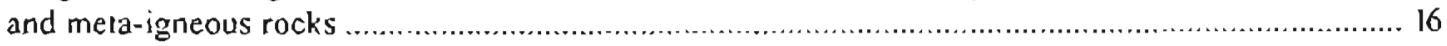

13. Diagram illustrating immobile element comparisons between late Paleozoic and Triassic metavolcanic rocks of the study area and potentially equivalent units from southern Alaska and eastern Yukon Territory....

12. Diagram illustrating compositional characteristics of Lace Cretaceous and early Tertiary inmusive rocks of the snudy area

13. Upper Permian limestone section

\section{TABLES}

Table I. Selected mineral deposits and prospects in the Chulitna mining district .................................. 3

${ }^{14} \mathrm{Ar}{ }^{39} \mathrm{Ar}$ age data for the Chulima mining district ........................................................... 6

\section{SHEET}

[in envelope]

Geologic map of the Chulima region, southcentral A laska 


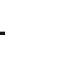




\title{
GEOLOGIC MAP OF THE CHULITNA REGION, SOUTHCENTRAL ALASKA
}

\author{
by \\ K.H. Clautice', R.J. Newberry², D.S. Pinney' R.B. Blodgett ${ }^{3}$, T.K. Bundtzen ${ }^{4}$. B.G. Gage ${ }^{2}$, E.E. Harris', \\ S.A. Liss'. M.L. Miller', R.R. Reifenstuhl', and J.G. Clough'
}

\section{INTRODUCTION}

The Chulitha region is located along A laska's major railbelt about 150 miles north of Anchorage and hosts the Golden Zone deposit as well as numerous prospects with intriguing values of gold, silver, copper, arsenic, and tin (fig. I). In an effort to better understand the geology and many known mineral deposits of this area along Alaska's nain transportation corridor, a study was initiated by DGGS in 1996 with a $364 \mathrm{mi}^{2}$ airborne aeromagnetic and electromagnetic survey (magnetic and resistivity) (DGGS and others, 1997a,b,c,d; Bums. 1997). In 1997, a twoyear geologic mapping effor began as follow-up to the airborne geophysical surveys. Because many of the bedrock units in the region have distincuve geophysical signatures, the airborne surveys proved to be extremely useful mapping tools to delineate both map units and smucture, particularly in areas of extensive surficial cover. A total of six weeks were spent in the field between 1997 and 1998 .

This report includes a comprehensive bedrock and surficial geologic map (sheet I) that is based on field observations. geophysical interpretation of bedrock contacts in areas of surficial cover, and air photo interpretation of

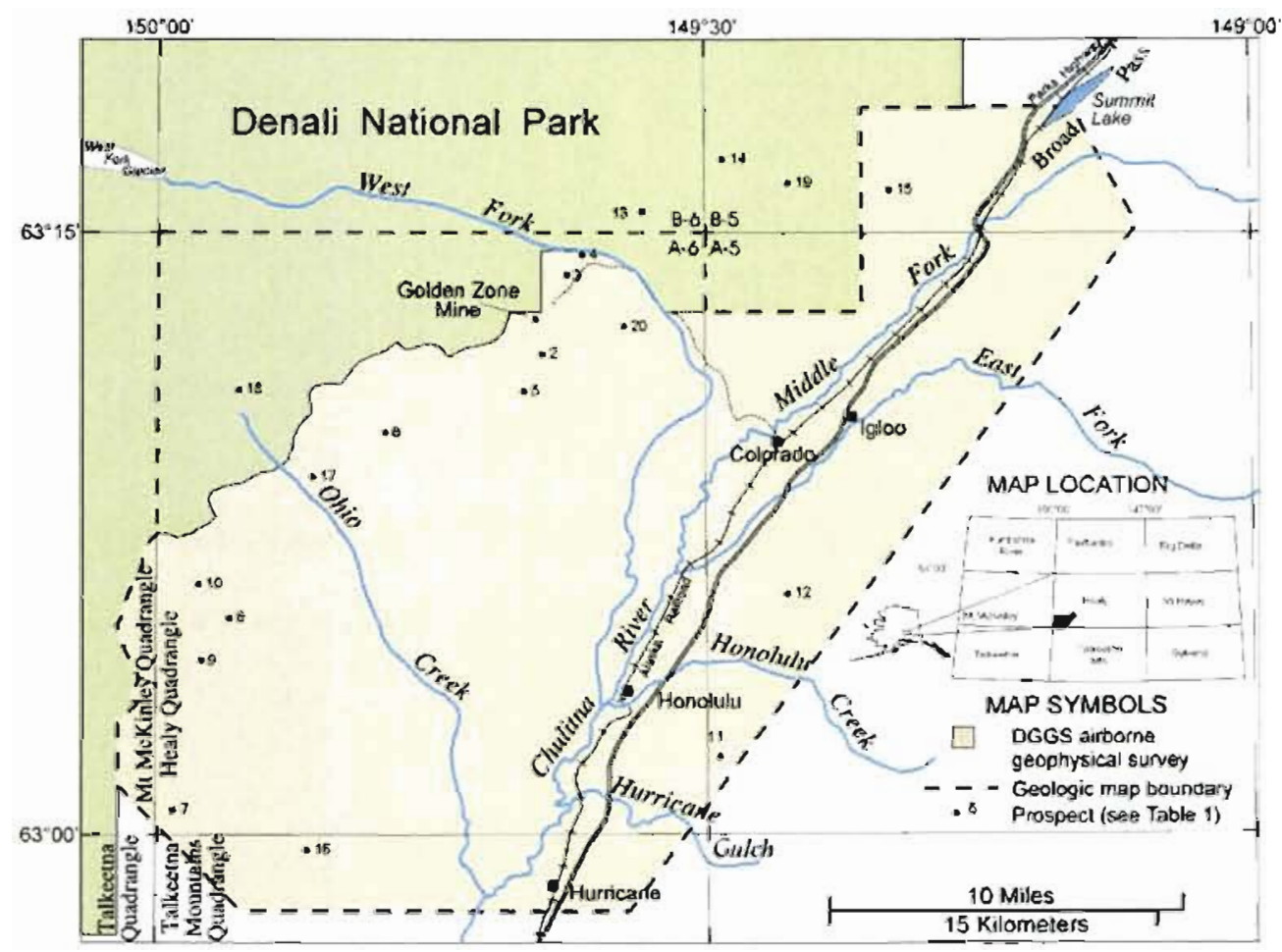

Figure 1. Chulitne area location map showing selected mineral deposits and prospects (listed in table 1), and boundories of airborne geophysical surves and geologic mapping.

\footnotetext{
'Alaska Division of Geological \& Geophysical Surveys. 794 Universily Avc.. Suite 200. Fairbanks. Alaska 99709-3645

2Universily of Alaska Farrbanks. Depariment of Geolngy \& Gcophysics. PO. Box 755780. Farrbanks. Alaska $99775-5780$ ? 1025 NW 261h Sireci. Corvallis Oregon 97330

DGGS at unc of fick mapping: now with Pacific Rim Genlogical Consulting. PO). Box 81906. Fairbanks, Alaska 99708

‘U.S. Gcological Survey, 4200 Universily Drive, Anchorage. Alaska 99508
} 
surficial units. The accompanying texi includes delailed sections on geochronology, regional struclure, economic geology, compositional characteristics of inajor igneous units, and unit descriptions. The major findings of this slindy include:

1. Trace element chemistry of the Trassic basalt in Chulitna terrane correlates with that of extensional Late Triassic Nikolai greenstone mapped ihroughout soulhem Alaska and contrasis strongly with basalt of similar age from Stukinia terrane.

2. While we recognize some classic redbeds ivithin the Chulina area, much of what was previously mapped as redbeds has a large volcanic component that chemically resembles calc-alkaline arc rocks.

3. Based on compositional, paleontological. and stratigraphic data. we believe that Chulitna is not a unique terrane as proposed by earlier workers, bu: is a variant of the Wrangellia terrane of eastern Alaska comprised of Chuliına, West Fork, and Broad Pass iersanes (Jones and others, 1981) of earlier usage.

4. Earlier workers (for example, Hawley and Clark, 1973, 1974) postulated two major periods and types of intrusion-related mineralization in the region (older Au-As vs. younger Sn-As). We have docllmented this age and magmatic distinction and present intmision- and mineralization-based compositional discriminators for the rwo major types.

5. We presene a stratigraphic and structural model for the district that appears to account for the distribufion of mineralization. It consists of a southeast-vergent, lightly folded and commonly overturned stratigraphy cut by north-nomheasttrending vertical faults. The intense norheast-trending folding is presumed to be associaled with early Late Cretaceous emplacement of the 'Wrangellia' sequence nbove Jurassic-Crelaceous nysch. Folding and faulting within major blocks provide weakened zones for the emplacement of plutonic-related mineralization; vertical novement berween faulted blocks determines the level at which mineralization will be found. For example, down-dropped blocks show little surface expression of mineralization or igneous rock and in places have preserved Tertiary coal beds. Conversely, blocks that display nodest 'up' movement contain the Paleozoic and Triassic stratigraphy, vein and breccia deposits, intrusive dikes and plugs, and the majority of the likely intrusion-related mineral resources. Finally: blocks with the greatest amounts of 'up' movement are dominated by the structurally underlying Jurassic and Cretaceous mysch and by extensive exposures of plutonic rocks ar levels well below their "roof" zones. As mineral deposits are largely located in the root zones of plutons. lhese deeper-level plutonic exposures are generally unfivorable for intrusion-related mineral deposits.

Additional repons resulting from the Chulitna district sludy relate to rock chemistry (Gage and others, 1998), comprehensive paleontology (Blodgett and Clautice, 2000), paleomagnetics (Sione and olhers, 1999), paleonlology (Won and others, 2000): Stanley and Yarnell, in press; and Fryda and Blodger, in press) and stratigraphy (Montayne and Whalen. in press). This report is part of a series (RI 200I-IA-D) which supersedes a series of preliminary maps of the Healy A-6 Quadrangle (the core of the Chulitna region) including interpretive bedrock and geologic maps (Clautice and ohers, 1999a.b) and Quaternary and engineering geology (Pinney. 1999a,b).

\section{PREVIOUS WORK}

Reports by eurly workers in the district include Brooks and Prindle (1911), Moflit (1915), and Capps (1919, 1940). Ross (1933) recognized fault-controlled mineralization. volcaniclastic rocks, and several major faults. Wahrhaflig ( 1944 ) described the area's coal deposits and engineering geology along the ncarby Alaska Railroad (Wahrhafig and Black, 1958). The geology and mineral deposits of the Upper Chulima district were first described in detail in a series of papers by Hawley and others (1968, 1969), Hawley and Clark (1973. 1974), and Clark and others (1972). Mulligan and others (1967) reported on sampling of the Golden Zone mine, and mineral deposits of the region have been described and sampled by Kurak and others (1992). Jones and others (1980) mapped (at a scale of $1: 63,360)$ and defined the Chulina terrane, which they considered to include an ophiolite assemblage, 10 be one of several allochthonous terranes in the district. Rock ages in their repor were established with extcnsive micro- and macro-fossil identifications. Csejtey and others (1992) published a compilation of the geology of the Healy Quadrangle. which showed the Chulima district to comprise a series of allochthonous stacked blocks thrust from the nonth over a basement of Cretaceous melange. Regional geology of southcentral A laska is summarized in a paper by Nokleberg and others (1994).

\section{REGIONAL GEOLOGY}

The Chulitna area is comprised of several nomheastrending belts of rocks of upper Paleozoic to Cretaceous age (herein referted to as the "older assemblage") bounded 10 both the northwest and southeast by Jurassic to Cretaceous nysch of the Kahilina assemblage (Reed and Nelson. 1980). Both the Kahiltna and older assemblages are sandwiched between Wrangellia tertane (Jones and others, 1981) to the south and the Denali fault and North 
Anerica craton or Yukon-Tanana terrane to the north. Published literature describes much of the Chulitna region as allochthonous terranes most likely accreted to Wrangellia and rafted north to collide with Norh A nuerica in the Late Cretaceous (Csejtey and others, 1992). Based on our mapping and petrology, we suggest instead that Chulitna may be part of Wrangellia and can be correlated with upper Paleozoic to Mesozoic rocks of the east-cenral Alaska Range and westem Yukon Territory, with a coinplex Cretaceous and younger siructural history accompanied by two major intrusive episodes. Our interpretation of the age and character of the units present in the map area (fig. 2) is that they represent only minor modifications of the late Paleozoic to Mesozoic stratigraphy seen throughout southern Alaska, including a mid-Paleozoic oceanic arc, a late Paleozoic to Early Triassic volcanic-sedimentary sequence, a Late Triassic rift-related basalt plus limestone sequence, and a Jurassic-Cretaceous flysch-dominated section. Radiometric age and compositional evidence is provided in this report, paleontologic evidence regarding the possible linkages is found in Blodgett and Clautice (2000).

\section{GEOCHRONOLOGY}

\section{METHODS}

Twenty-seven rocks from the study area wore prepared for ${ }^{40} \mathrm{Ar} \cdot{ }^{19}$ Ar dating with monomineralic separates of appropriale K-rich minerals (table 1). After inadiation, the mineral separates were analyzed by siep heating. using a 6-watt argon-ion laser, as described in Layer and others (1987). On average, 12-16 fractions were collected for eacls sample. Samples of homblende MMhbl (Samson and Alexander. 1987) with an age of 513.9 Ma were included with eacli set of unknowns to monitor the neutron flux. Each gas fraciion was analyzed for Ar isotopic ratios in a VG-3600 mass spectrometer at the Geopliysical Institute. University of Alaska Fairbanks. The argon isotopes measured were correcled for system blank and mass discrimination, as well as calcium, potassium, and chlorine interference. Apparent ages and 1 sigma uncertainties were calculated for each fraction using the constants of Steiger and Jaeger (1977).

Table 1. Selected nimeral deposis and prospects in the Chulima mining district. Locations are indicaled on figure 1.

\title{
Map no. Prospect Longitude Latitude Brief description
}

\section{Mincralization associnted with late Cretaceous intrusions}

$\begin{array}{llll}1 & \text { Golden Zone } & -149.650 & 63.214 \\ 2 & \text { Copper King } & -149.644 & 63.199 \\ 3 & \text { Banner } & -149.622 & 63.232 \\ 4 & \text { Riverside } & -149.606 & 63.240 \\ 5 & \text { Long Creek } & -149.660 & 63.184 \\ 6 & \text { Kennicor } & -149.931 & 63.089 \\ 7 & \text { Eldridge Glacier } & -149.983 & 63.010 \\ & & & \\ 8 & \text { Silver Kitty (a) } & -149.788 & 63.166 \\ & \text { Silver Killy (b) } & -149.788 & 63.166 \\ 9 & \text { Partin Creek } & -149.957 & 63.071 \\ 10 & \text { McCallic Glacier Lode } & -149.959 & 63.103 \\ 11 & \text { Honolulu } & -149.482 & 63.031 \\ 12 & \text { Antimony } & -149.420 & 63.099 \\ 13 & \text { Silver King } & -149.553 & 63.258 \\ 14 & \text { Nimbus } & -149.480 & 63.280 \\ 15 & \text { B-5 } & -149.327 & 63.267\end{array}$

\author{
As-Au-Cu-Ag brecciápipe \\ Cu-Au skam (and porphyry Cu?) \\ As-Au-Ag skam \\ As-Au-Ag vein and sullide replacements \\ As-Au-Ag veins and veinlets in homfels \\ Disseminated sulfides in altered dikes? \\ Disseminaled sulfides in listwanite (quarz-carbonate \\ altered serpentinite) zone \\ Au-As initusive stockwork \\ Disseminated As-Au-Ag in homfels near mafic stock \\ $\mathrm{Cu}-\mathrm{Au}$ veins, skarns, and carbonate replacements \\ As-Au-Ag veins and sulfide replacements \\ As-Ag-Au vein \\ $\mathrm{Sb}-\mathrm{Au}-\mathrm{Ag}$ vein \\ As-Au-Ag skams and veins \\ As-Au-Ag vein and sulfide replacements \\ As-Au mineralized homfels zone
}

\section{Mineralization associated with early Tertiary intrusions}

\begin{tabular}{lllll}
16 & Coal Creek tin & -149.861 & 62.993 & Sn-Ag greisen \\
17 & Ready Cash & -149.854 & 63.148 & Ag-Sn-Zn skams, sulfide replacements, and veins \\
18 & Ohio Creck & -149.921 & 63.184 & Sn-Aggreisen and minor Zn-Ag Skarn \\
19 & Nim & -149.420 & 63.270 & Low-F porphyry Mo("?) and distal veins \\
20 & Lookout Mountain & -149.569 & 63.211 & Distal (?) Sn-Ag tounnaline stockwork \\
\hline
\end{tabular}




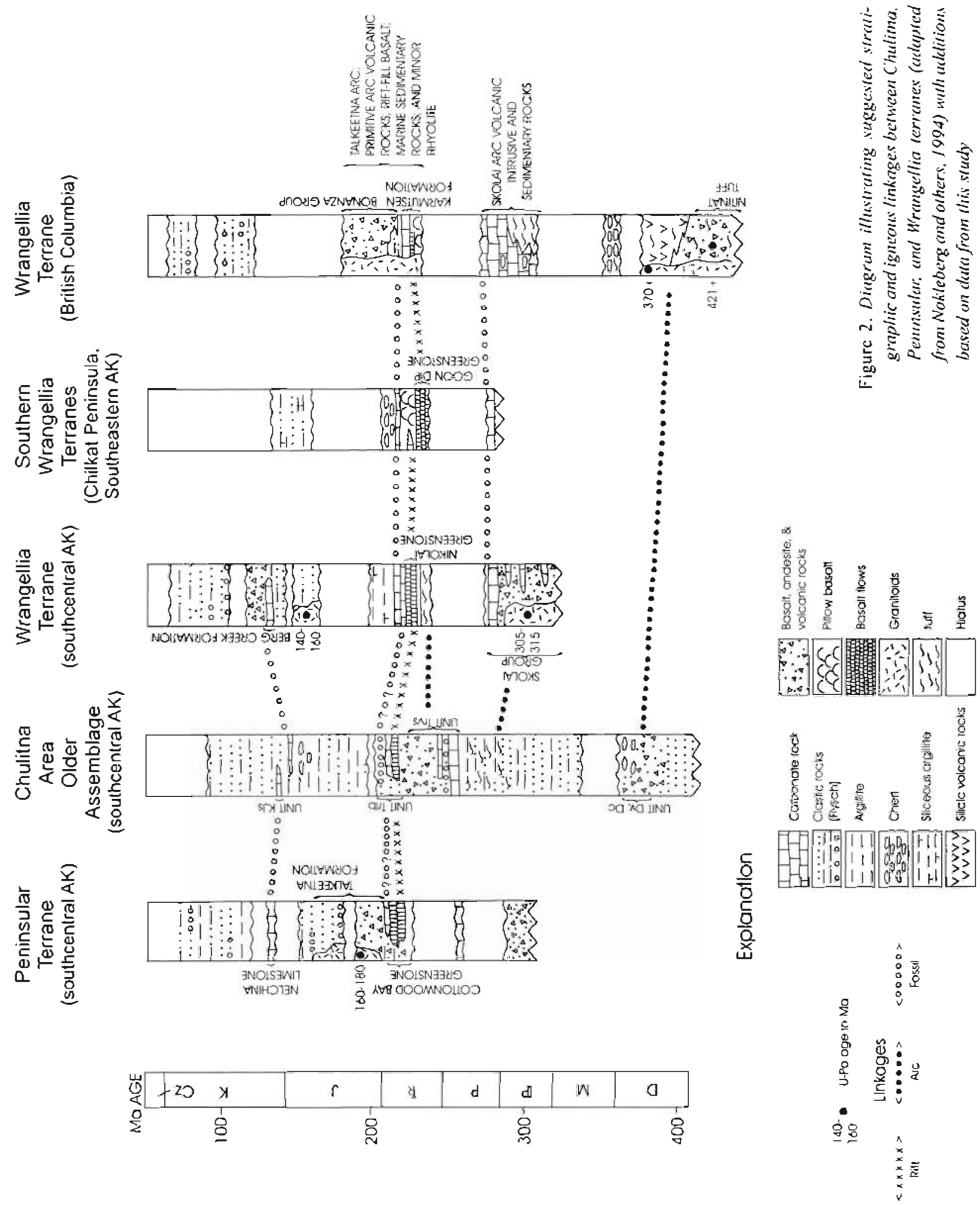


For each sample the "integtated age" (the weighted average of each fraction age) was calculated to facilitate comparison with previously determined $K-A$ r ages. Where three or more consecutive heating steps yielded the same age ( $t+1$ sigma). which accounted for more than 50) percent of the released $A r$, the weighted average of shese steps was calculated as the "plateau age." Where significant isotopic variations occurted benveen individual steps, an isochron age was calculated from the ${ }^{\sqrt{0}} \mathrm{Ar} /{ }^{39} \mathrm{Ar}$ and ${ }^{40} \mathrm{Ar} /{ }^{30} \mathrm{Ar}$ ratios. This age was considered significant only if the Mean Square Weighted Deviation (MSWD) was less than 2.5. For several sámples, the last 10 percent or so of gas release yielded an age significantly older than the plateau or isochron age. Because such ages reflect a phase or domain that was less affected by Ar diffusional loss than the bulk of the mineral, they are both indicators of complex thermal history and yield minimum ages of mineral formation. In many such cases, while the Arspectrum technically safisfied the criteria for a plateau, increasingly older ages for fractions released at increasing temperature ("pseudo plateau") also indicate that the "plateau" age is not a valid measure of the true age.

Lacking anomalous ages for either the higher- or lower-temperanure fractions, the interpreted age of the sample was taken to be the isochron (preferred) or plateau age. If neither a plateau nor an isochron (with an MSWD <2.5) could be generaced from the step-release healing, then the integrated age was taken as a minimum estimate of the age of mineral formation or re-heating.
Where a clearly defined, anomalously old. high-temperaure fraction age was determined, this age was taken as a minimum age.

\section{RESULTS}

The results of the step-heating Ar measurements, summarized in table 2, indicate that most of the rocks examined experienced complex thermal histories. In particular, all the pre-Jurussic rocks sampled experienced partial 10 complete Ar loss, indicated by plateau and isochron ages of $1451065 \mathrm{Ma}$ (table 2). Because Late Cretaceous igneous rocks are limited to small stocks and dikes, this extensive degree of re-heating requires that major igneous bodies of Late Cretaceous age nust underlie the Chulsma region. This, in conjunction with the major igneous intrusions in the structural blocks east and west of the Chulitna block, indicates nuajor vertical movements along the high-angle faults bounding the Chulitna block (fig. 3).

The intrusive rock ages also show that some previous age assignments are incorrect. In particular, all mafic intrusions in the region were previously assigned a Tertiary age (Hawley and Clark, 1974); this study (table 2) shows that some are Tertiary $(98 \mathrm{KC} 124)$, some are Late Cretaceous (97R N336), and some are pre-Cretaceous (97RN438). In particular, because pre-Cretaceous mafic inousions represented by sample 97R 438 (minimum age of $179 \mathrm{Ma}$ ) are compositionally indistinguishable from basalt flows interlayered with Late Triassic megafauna

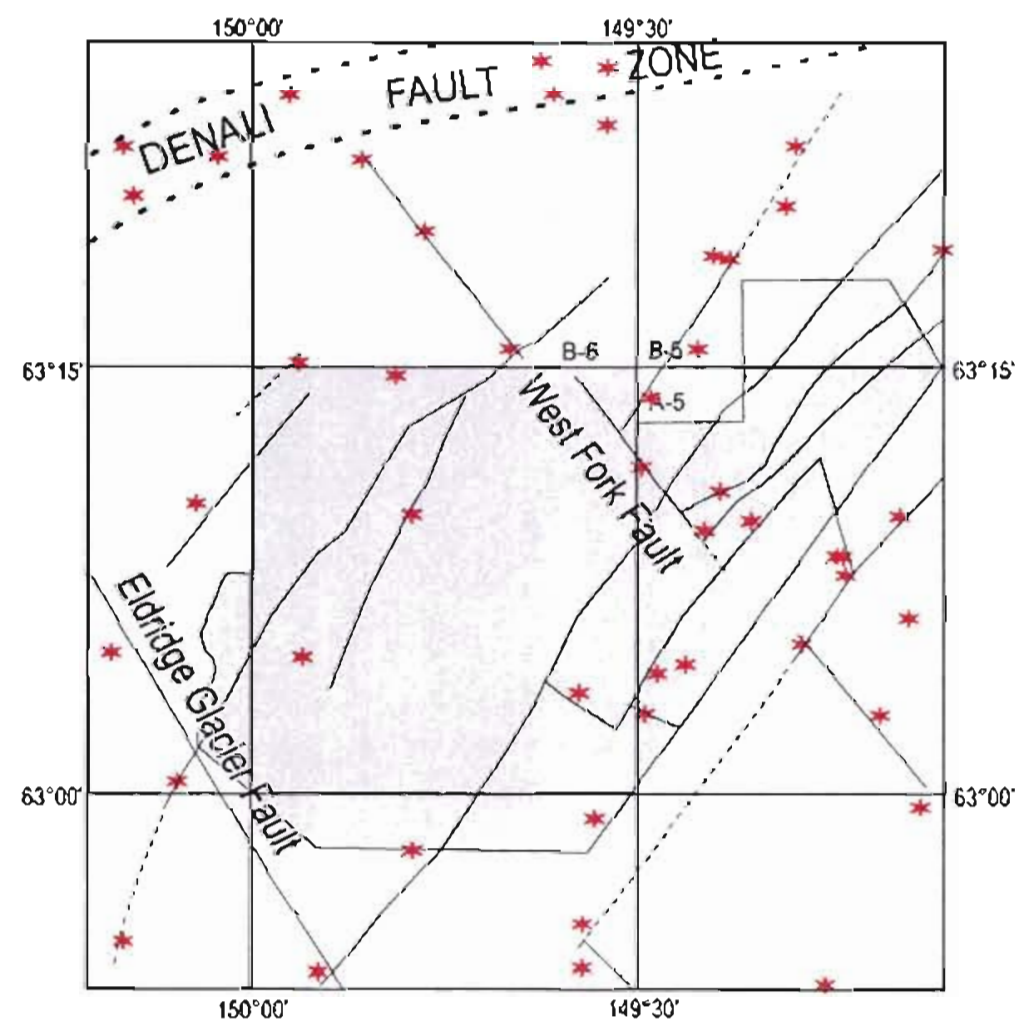

Figure 3. Simplified struchural map of the Chulima district. showing interpreled high-angle fauls and shallow $(<20 \mathrm{~km})$ earlhquake epicenters (shown as stars) for 1990-1996. Because the earthquake foci are up $1020 \mathrm{~km}$ bclow the surface, and the ascociated foults have dips of $75-85^{\circ}$ (not sirictly verfical). a given epicenser can be located up $105 \mathrm{~km}$ down-dip from the surSac'e irace of the associaled fault. Earlinquake epicenter and focal depih dala courtery of the U.S Geological Survey. Alaska Earthumakt Information Center. 


\begin{tabular}{|c|c|c|c|c|c|c|c|c|}
\hline Sample & Unit & Locat & tion & Rack woe & Mlineral" & Interpreted & Integrated & Comments \\
\hline $97 \mathrm{AM} 222$ & $u P \% ?$ & -149.658 & 63.157 & Melatuff breccia & Amph & $>70 \pm 1.5(\mathrm{~h})$ & $613 \pm 0.5$ & Pscudo plateau $=65 \mathrm{Ma}$, resel $35 \pm 5 \mathrm{Ma}$ \\
\hline $97 \mathrm{BT} 200$ & TRus & -149.646 & 63.199 & Retrograde skam & Ho & $>59.9 \pm 0.3$ & $60.2+0.3$ & $\begin{array}{l}\text { Copper King prospect-Good platcul, but Cl/K spectrum suggests } \\
\text { resct }\end{array}$ \\
\hline $97 K C 281$ & $\mathrm{Km}$ & -149.457 & 63.071 & Quartz monsodiorite & $\mathrm{Bi}$ & $67.8 \pm 0.3$ & $67.6 \pm 0.3$ & Partin Creck Prospecl—Highesl T fracion $70 \pm 2 \mathrm{Mu}$ \\
\hline $97 K C 301$ & TRs & -150.001 & 63.049 & Quartz diorilc dike & Ho & $68.0 \pm 0.3$ & $68.6 \pm 0.3$ & $\begin{array}{l}\text { Near Eldridge Glacier prospect-Isochron } 07.4 \pm 0.3 \text {; High T age } \\
74 \pm 5 \mathrm{Ma}\end{array}$ \\
\hline $97 K C 339$ & IR:s & $-149,931$ & 63.689 & Alterod porphyry dike & WR & $58.6 \pm 0.2(1)$ & $58.6 \pm 0.2$ & $\begin{array}{l}\text { Kennicotl prospect-Resel = } 55 \mathrm{Ma} \text {, no plateau or Isochrin, age } \\
\text { probably }>59 \mathrm{Ma}\end{array}$ \\
\hline \multirow[t]{2}{*}{$97 \mathrm{~K} \times 360$} & TRIb & .149 .957 & 63.071 & Mlered homfols & Bi & $75.5 \pm 0.4$ & $67.9 \pm 0.4$ & Parin Creek Prospect-Pseudo plareau, altered spectra, cxcess agc? \\
\hline & & & & & Mu & $70.9 \pm 0.5$ & $67.7 \pm 0.6$ & Partin Creck Prospect-Pscudo platuat; resel at $=30 \mathrm{Ma}$ \\
\hline YTRN330C & TRus & -149.553 & 63.258 & Skim & Ho & $63.7 \pm 0.3$ & $63.3 \pm 0.4$ & Silver King-Good plateau; reset at -40 \& $10 \mathrm{Ma}$ Healy B- 6 \\
\hline 97RN334 & $\mathrm{K} ? \mathrm{~g}$ & -149.477 & 63.245 & Granite dike & $\mathrm{Ksp}$ & $61.4 \pm 0.3$ & $61.5 \pm 0.3$ & $\begin{array}{l}\text { Healy B-5. VABM Bull—Good pleteau. but Kapar ages are }< \\
\text { magnialic age }\end{array}$ \\
\hline $97 R N 330$ & Km & -149.628 & 63.190 & Alkalic? dike & Ho & $66.7 \pm 0.9$ & $68.0 \pm 1.1$ & Good plateau, fia ir precision \\
\hline $97 R N 348 C$ & $\mathrm{Tg}_{\mathrm{g}}$ & -149.921 & 63.184 & Greisen & Mu & $55.0 \pm 0.2$ & $55.4 \pm 0.3$ & Ohro Creek prospect-Good plateau \\
\hline $97 R N 377 K$ & $\mathrm{Kg}$ & -149.644 & 63.199 & Altered granice porphyry & $\mathrm{Bi}$ & $66.2 \pm 0.4$ & $63.8 \pm 0.3$ & Copper King core-Ar loss - 30 Ma, nodel age $=67 \mathrm{Ma}$ \\
\hline $97 R N 398$ & Dv & -149.752 & 03.131 & Mela-andesile flow & Amph & $68 \pm 2.4(i)$ & $\begin{array}{c}106=9 \\
79.4 \pm 1.3\end{array}$ & Secondary (?) actinolitic amphibole: isochron represents resel age \\
\hline $97 \mathrm{RN} 407 \mathrm{D}$ & TRvs & -149.771 & 63.133 & Andesitesill & Pyx & $>177(1)$ & $\begin{array}{l}199 \pm 352 \\
177 \pm 24\end{array}$ & $\begin{array}{l}\text { Very poor precisıon; significant Ar loss: 130chron al } \\
145 \pm 15 \mathrm{Ma}=\text { resel age? }\end{array}$ \\
\hline 97RN408B & $\mathrm{Km}$ & -149.788 & 63.166 & Diorite pluton & $\mathrm{Bi}$ & $>70.6 \pm 1.6(\mathrm{~h})$ & $66.3 \pm 0.3$ & $\begin{array}{l}\text { Silver Kitly Prospect-Pseudo plateau al } 66.4 \pm 0.3 \mathrm{Ma} \text {, luigh } \mathrm{l} \\
\text { fraction mostly homblende }\end{array}$ \\
\hline $97 R N 438$ & TRb & -149.808 & 03.141 & Gabbro body & Pyx & $>179(1)$ & $179 \pm 7$ & Ar loss; isochron al $117 \pm 5 \mathrm{Ma}=$ resel age? \\
\hline $97 R N 49 S C$ & km & -149.864 & 63.120 & Biolite diorite & $\mathrm{Bi}$ & $66.8 \pm 0.3$ & $06.8 \pm 0.3$ & Good plateau: no loss. \\
\hline 97RN507A & $\mathrm{kg}$ & -149.490 & 63.016 & Granite pluton & $\mathrm{Bi}+\mathrm{Ho}_{0}$ & $>65 \pm 0.7(h)$ & $\begin{array}{l}51.6 \pm 0.7 \\
54.6 \pm 1.1\end{array}$ & $\begin{array}{l}\text { High T fraction mostly homblende: Ar loss }=20 \mathrm{Ma} \text {; preudo plateau } \\
\text { dt } 64.2 \pm 1.4 \mathrm{Ma}\end{array}$ \\
\hline 97RN513A & TRH & -149.854 & 63.148 & Mineralized hornfels & Ho & $57.6 \pm 0.6$ & $54.8 \pm 0.7$ & Ready Cash-High "T fruction $67.7 \pm 7.0 \mathrm{Ma}$; resei $32 \mathrm{Ma}$ \\
\hline $97 R R 146 C$ & $\mathrm{Tg}$ & -149.700 & 63.147 & Granite dike & $\mathrm{Bi}$ & $46.0 \pm 0.3$ & $45.9 \pm 0.3$ & Good platean; no obvious resel \\
\hline $97 S L 399 B$ & $\mathrm{Km}$ & -149.653 & 63.239 & Matic dike & Ho & $66.8 \pm 0.3$ & $66.9 \pm 0.4$ & Blind Creek-High T fraction $69 \pm 4 \mathrm{Ma}$; slight hump \\
\hline
\end{tabular}




\begin{tabular}{|c|c|c|c|c|c|c|c|c|}
\hline $\begin{array}{l}\text { Sample } \\
\text { Number }\end{array}$ & Unit & $\begin{array}{r}\text { Locat } \\
\text { Longitude }\end{array}$ & $\begin{array}{l}\text { lon } \\
\text { Latitude }\end{array}$ & Rock type & Minerat" & $\begin{array}{l}\text { Interpreted } \\
\text { Age (Ma) }\end{array}$ & $\begin{array}{l}\text { Integrated } \\
\text { age (Ma)d }\end{array}$ & Comments: \\
\hline 98BG149 & $\mathrm{Km}$ & -149.650 & 63.214 & Biolite monzodiorite & $\mathrm{Bi}$ & $69.3 \pm 0.6$ & $68.0 \pm 0.6$ & $\begin{array}{l}\text { Golden Zone deposit-Model age } 69.4 \text { Ma with reser }=23 \text { Ma: } \\
\text { similar isochron age }\end{array}$ \\
\hline $98 \mathrm{BGi} 61$ & $\mathrm{Knn}$ & $-149,650$ & 63.214 & Biotic monrodiorite & Bî̀ & $70.1 \pm .9(0)$ & $67.4 \pm 0.6$ & Golden Zone deposil-Pseudo plateau al $70 \pm 0.5 \mathrm{Ma}$ zero-age tesel \\
\hline $98 \mathrm{HA}, 1$ & $\mathrm{Kg}$ & -149.486 & 63.009 & Granite chill margin & $\mathrm{Bi}$ & $>71 \div 3(\mathrm{~h})$ & $49.8 \pm 0.4$ & Healy A-S-Major Ar loss $=16 \mathrm{Ma}$; rseudo plateau di $60.5 \pm 1 \mathrm{Ma}$ \\
\hline 98HA5SB & Dr & -149.327 & 63.267 & Homfelsed volcanic & $\mathrm{Bi}$ & $72.7 \pm 0.4(i)$ & $70.5 \pm 0.3$ & $\begin{array}{l}\text { Healy B5, TI9S R9W SI7-Complex age spectrum, sinilar pluteau } \\
\text { agc; resel } \approx 25 \mathrm{Ma}\end{array}$ \\
\hline $98 \mathrm{KCl} 24$ & $\mathrm{~Tb}$ & .149 .483 & 63.032 & Diabase dikc & Ho & $52.4 \pm 0.2$ & $51.4 \pm 0.2$ & Healy A $-5-$ Complcx spectra: rescI $\approx 35-40 \mathrm{Ma}$ \\
\hline 98RN50G & $\mathrm{PI}$ & .149 .622 & 63.231 & Skam & Ho & $69.9 \pm 0.9(\mathrm{i})$ & $71.1 \pm 0.8$ & Complex age spectrum: similar plateal age \\
\hline $\operatorname{ccs} 36-659$ & $T_{\mathrm{g}}$ & -149.861 & 62.99 .3 & Sn-greisen & Mu & $5.3 .4 \pm 0.2$ & $53.7 \pm 0.2$ & $\begin{array}{l}\text { Talkeetna Mounlans D-6. Coal Creck tin deposs-Plateau = } \\
\text { isochron age }\end{array}$ \\
\hline
\end{tabular}

Analyses performed by P. Layer and 1. Drake, University of Alaska Geochronology Laboratory, Geophysical Institule, University of Aluska, Fairbanks, Alaska

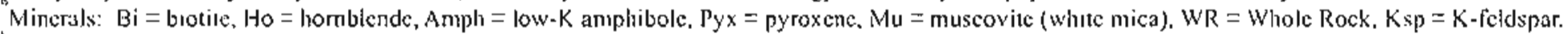

'Unless noted otherwise, interpreted ages are platesu ages: I = Integrateỏ age, $\mathrm{i}=$ isochron age, $\mathrm{h}=$ age of highest-lemperature fraction (minimum age). Ages reporled at \pm Is:

Equivalent to a conventional K-Ar age, and given for comparison purposes only. 
(unit TRIb). it is most likely that these intrusions are also of Late Triassic age. Further, since such intrusions are conposicionally distinguishable from post-Jurassic ones and intrude unit TRus ("red beds" of Jones and others, 1980), unit TRvs mms/ be older than unit TRIb, and not younger (as inferred by Jones and others. 1980). Such age relationships have vital importance with respect 10 structural interpretations in the A-6 quadrangle. indicating that many of the thrust faulis inferred by lones and others (1980) are not present.

Tertiary intrusions also coused themal rescts. however, as indicated by disturbances in specira of several Late Cretaceous plutons and dikes (table 2). Igneous and contact metamorphic rocks from the Partin Creek prospect, for example, yield plateau ages of 76,71 , and 68 Ma. Further, the samples yielding younger plateau ages also gave high-temperature fractions with ages significamily older than the plateau age, indicating post-Cretaceous thermal disturbance. Such results indicate that interpreted ages of Late Cretaceous mineralization and igneous rocks must be vicwed with the potential for later thermal resets in mind.

Conventiona! $\mathrm{K}$-Ar dates previously determined for the large granite intrusion barely in the southeast corner of the A-6 quadrangle indicated an early Teniary age (Csejtey and others, 1992). Our samples (97RN507, $98 \mathrm{HAl1}$; table 2) also yielded early Tertiary integrated (= K-Ar equivalent) ages, but Late Cretaceous pseudo plateau and high-temperature fraction ages indicate the intrusion is instead of Late Cretaceous age. This result has important regional inplications, as it demonstrates that not all of the so-called "McKinley age" granites (based on K-Ar ages or general appearance) are of early Terliary age. Further, since "McKinley age" granites are generally considered favorable for $\mathrm{Sn}-\mathrm{Ag}$ deposits. but unfavorable for Au deposits (for exanple, Light and others. 1990) the lode gold potential for the region is likely underestimated.

\section{STRUCTURE}

The dominant struceures in the Chulima district are high-angle faults (fig. 3), as indicated by linear patterns of shallow earhquake epicenters. Early warkers (for example, Hawley and Clark. 1974) mapped these as high-angle fauls becuuse therr nearly straight-line surface traces show no deflection by the greater than $2 \mathrm{~km}$ topographic relief. Subsequent workers (Jones and others, 1980; Csejcey and others, 1992) mapped these as [moderate- 10 high-angle] thrust fauts 10 accommodate their geologic model of terrane collision. However, these fauls, which can be traced both on the ground and by linear zones of high conductivity, show abnupt breaks on aeromagnelic maps, indicating they are very sreeply dipping.
High-angle lauls (rend mainly norheast, northwest, and north-northeast in the map area. Northerst-mending faults are the mosi concinuous and appear to have the grealest displaceinent. The norheast faults define the Broad Pass graben and the nonhwestem margin of the Paleozoic Chulina) block. We huve no direct evidence for the amount of horizontal movernell, but the orientation of this norheast-trending fault set suggests that it is related to the Denali fault: thus it may have significant horizonal movement. Verlical displacement of more than a kilometer is suggested by Latte Cretaceous and Tertiary plutons, which intude the Chulitna block (that we believe is in thrust contact above the younger Jurassic-Cretaceous flysch) as high-level dikes and plugs, yet are well exposed and deeply eroded across the northeast bounding faulss within Iurassic-Cretaceous flysch.

The second mosi imponant fault set is the group conraining the northwest-trending fauts. They are approximately $201030 \mathrm{~km}$ apart and are probably formed as conjugate pairs to the norheast-rending faults. Horizontal and vertical offsets of a few kilometers are likely. Veins and dikes are commonly oriented parallel to the northeast-trending fisults. and less commonly parallel to the northwest-trending faults. Such evidence suggests that this faulting began by approximately $70 \mathrm{Ma}$.

The most abundant faults. but with smallest apparent offset, are the north-northeast-trending set. Earthquake epicenters appear to outline only a few of these (fig. 3), although their topographic expression and minor movenent suggest a recent origin. These fauls appear to have largely strike-slip movement of less then a few kilometers and truncate against the major, block-defining, northeast-1rending faulis. A young age is also indicated by the fact that these faults offset veins, skams, and mineralized Late Cretaceous plutons (sheet I, photo I). Tracing mineralization patterns is severely complicated by these younger faults.

Several sets of structures pre-date the high-angle faults: it is difficult to define or trace these older structures. Although there is no direct evidence for low-angle faults in the Chulitna district, indirect evidence suggests that the Paleozoic Chulitna block sits stmcturally above the extensive Kahiltra assemblage along a low-ingle fault surface. The most striking evidence comes from the Late Cretaceous and early Tertiary intrusive rocks in the region. Such inmusions cut all pre-Tertiary rocks in the region, but their outcrop sizes vary dramatically between the major fault blocks. Intrusions with indistinguishable ages and compositions occur as large plutons to batholithsized bodies in unit KJas, but as dikes or small plugs within the Paleozoic block. Given that the intrusions into KJas commonly occur at higher present elevations than the dikes and plugs in the Chulitna block. these differences can be most readily ascribed to major, post-inrrusive uplifi of KJas blocks relative to the Palenzoic blocks. Such 
a relationship, in rum. requires that the Paleozoic rocks be structurally above KJas, hence in thrust contact.

The major struclural style within the Chulirna block is a series of northeast- 10 north-northeast-plunging, tight, overturned folds, with both limbs dipping to the northwest. Fold wavelength is approximately $\mathrm{l}-2 \mathrm{~km}$, and becomes tighter towards the center of the block. Folds in the central pan apparently involve the oldest units and are cored by irregular pods of party serpentinized malic/ ultramafic rocks and serpentinite. Southeast of the strongly folded area are poorly exposed units consisting of weakly metamorphosed tuffs and sediments, within which lack of detailed stratigraphy has not allowed mapping of folds. Similarly, northeast-trending folds were not mapped in the Kahilma assemblage northwest of the Chulima block, although the lenticular distribution of subunits is consistent with the presence of relatively tight, commonly isoclinal, folds. This folding most likely accompanied stuctural emplacement of the Chulitna block, as the folds are cut by undeformed plutons and high-angle faults.

In summary, we infer the siructural style of the Chulitna block (units Dv through KJs) to be a tightly folded stratigraphy thrust and overlumed toward the south, and subsequently cut by extensive high-angle fault systems Faulting is dominated by a large northeast-trending graben, or down-dropped block, through Broad Pass in which Teriary gravels have been preserved. Vertical faults parallel to the graben occur on either side of Broad Pass. Vertical movement between northeast-trending blocks controls the erosional level of exposure of mineralizing plutons and thus surface expressions of mineralization in the region.

\section{ECONOMIC GEOLOGY}

The only recorded metal production from the Chulitma district is from the Golden Zone deposit (fig. 1). Between 1941 and 1942 it produced 1,581 oz Au, 8,617 oz Ag, 21 tons $C u$, and I. 5 tons $P b$ (figs. 4 and 5). A small amount of placer gold was mined from Bryn Mawr Creek, immediately downstream from the Golden Zone, and from McCallie Creek, in the westem part of the quadrangle. Field descriptions and assay data for major prospects are given in Hawley and Clark (1974). Kurtak and others (1992), and Gage and others (1998).

Stratiform, syngenetic/diagenelic deposits appear 10 be rare or nonexistent in the Chulitna district Although voicanic rocks that evidently erupted into aqueous environments are common in the A-6 quadrangle, there is no evidence for submarine hydrothermal activity or volcanogenic massive sulfide deposils. Because the Permo-Triassic unit ( $T R v s$ ) formerly referred to as "sedimentary redbeds" (Jones and others. 1980) consists principally of iron-rich, mafic volcaniclastic rocks and associated sediments, and is not a "redbed" in the commonly accepted sense of a hematitic sandstone, there is no likelihood of redbed-associated Cu deposits in this unit. Basalt-hosted and basalt-associated Cu deposits, which

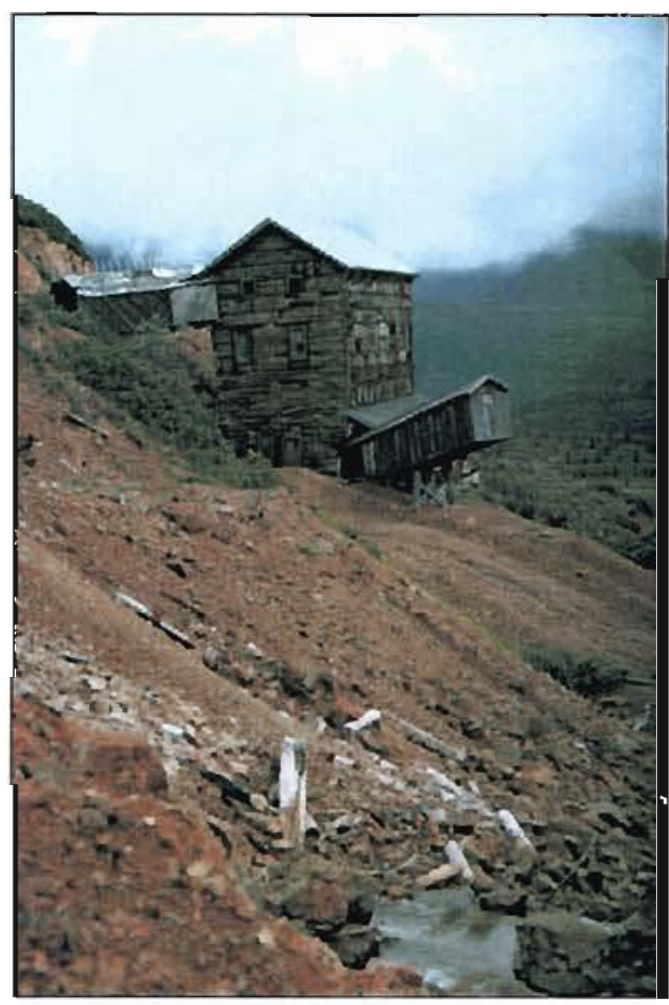

Figure 4 (lefi). The Golden Zone Mine mill. which wes built in 1939-40 and in ure during 1941-42, when the Golden Zone produced 1.581 oz All. \$.617 o: Ag. 21 lonx Cu, and aboul $3000 \mathrm{lb} \mathrm{Pb}$ from 1,730 cons of ore (Howley and Clark. 1974) (1997 phoro by M.L. Miller).

Figure 5 (below). C.C. Howley showing M.L. Miller the c'antacl between the ore body brecial (below) and the smongly joinced Cresaccous mon:o. nise, (unir Km. above) al the Golden Zone Mine (pholo by K. H. Claulice).

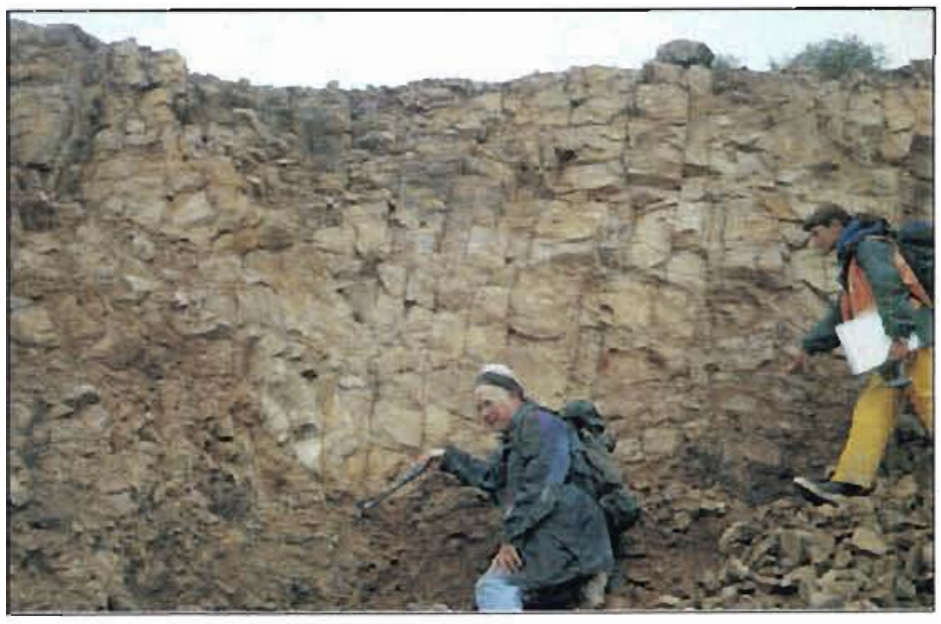


are common in-and stratigraphically above-Late Triassic basals elsewhere in the nonlawest Cordillera, are only present in areas with thick accumulations of subaerial basalt (Mackevell and others, 1997). As the equivalent basalt units in the A- 6 quadrangle are thin and interbedded with carbonate rocks, this mineralization style is also unlıkely in the area. Placer gold accumulations are not significant. as the area has been eroded by multiple glaciation events in the recent past.

Very small bodies of chromite are presenl within serpentinite in at least two locations in the A-6 quadrangle (Hawley and Clark, 1974). Neiher occurrence is of significant size. and given the exrremely discontinuous and faulted nature of the serpentinite bodies, there is limited likelihood for a large chromite accumulation in the quadrangle. Although small amounts of disseninated or veinlet pyrite have been noted in some altered gabbroic rocks of the region, no magmatic sulfides have been identified, and no significant $C_{1}-N_{1}$ or platínum-group metal anomalies have been found in the mafic intrusions (Hawley and Clark, 1974; Kurlak and olhers, 1992; Gage and others. 1998).
The majority of known mineral resources in the Chulitna district (table I) are spatially and cemporally (table 2) associated with Cretaceous and Teriary age intermediate to felsic intrusions. Although the various prospecis and deposits possess similarities, those associated with Late Cretaceous intrusions are fundamentally different from those with early Tertiary inmusions. The former contain significant Au resources and the latter significant Ag-Sn. Hawley and Clark (1974) drew similar conclusions, but regarded all the intermediate-composition intrusions as older. Au-related, and all the felsic-composition intrusions (including Cretaceous granite types) as younger. Sn related. In many cases the two deposit types are difficult to distinguish. Arsenopyrite and pyrite are chardateristic minerals of both types and anomalous concentrations of $\mathrm{Sn}$. Bi, Tc, and Au can be found in either type (Hawley and Clark, 1974; Wamer and Dahlin, 1989: Kunak and others, 1992; Gage and others, 1998). Empirically, however, the two types can be distinguished by their $\mathrm{Au}$ and $\mathrm{Ag}$ contents: the $\mathrm{Ag} / \mathrm{Au}$ ratios are invariably higher in mosı hand samples from the Sn-Ag type than in hand samples from the Au lype (fig. 6). When

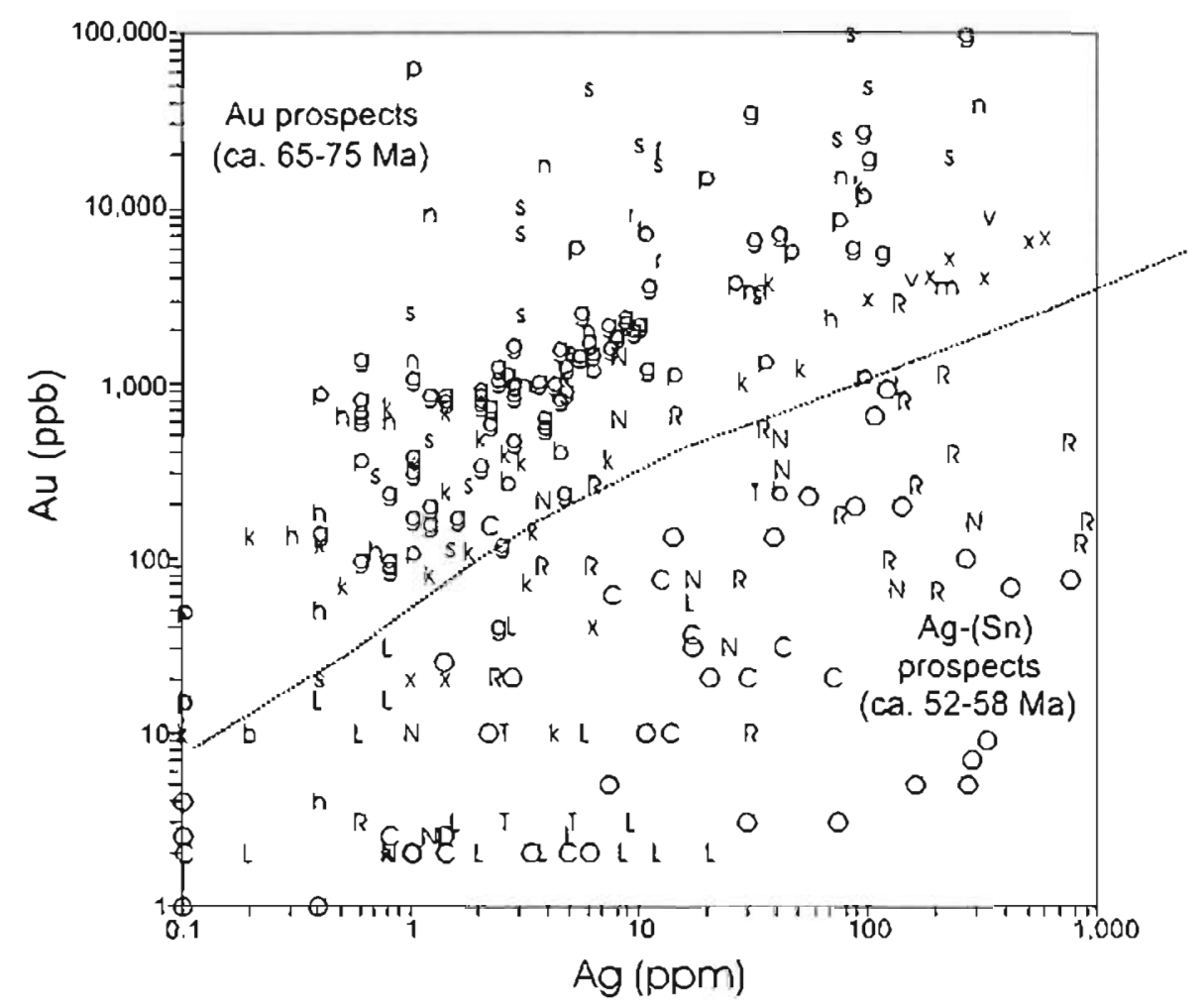

Figure 6. Concentrations of silver us. gold in mineralized samples from the Chulima area. Prospect ablureviations: Golken Zone and nearby prospecs $=g$. Riverside $=r$. Eas Vein $=v$. Bamer (skarn) $=b$. Copper King $=k$. Silver King $=x$. Long Creck $=x$, Homoluh $=h$, Nim $=$ n. Patin Creek $=p$, Mc Callie Glacier $=m$. Loskoul Mountain $=L$. Ohis Creek $=O$. Coal

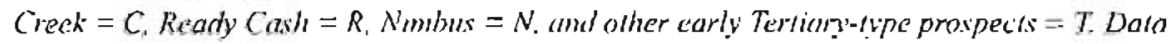
from Hawley und Clark (1974). Warner und Dahtin (1989). Kurick (1902). Newberry (1995). and Grage and olliers (1998). 
broken into these nwo types. based on $\mathrm{Au}$ and $\mathrm{Ag}$ contents, incerpreted minimum ${ }^{40} \mathrm{~A} r{ }^{39}$ Ar ages for mineralized and associated rocks mostly fall into two groups: 65-75 $\mathrm{Ma}$ for the Au rype and 52-58 Ma for the Sn-Ag type (fig. 7). Thermal resetting of some older mineralization by early Tertiary dikes and intrusions appears to account for the majority of overlap berween the two types.

Plutonic-related vein/breccia gold deposits in the region are exemplified by the Golden Zone deposit (Hawley and Clark, 1974). These deposits are spatially associaced with reduced (low primary magnetite) granitic rocks ranging from intermediate to felsic compositions. The ores contain abundant arsenopyrite, pyrite, and commonly pyrhotite, with lesser stibnite and/or ancimony-sultosalts. molybdenite, bismuthinite, $\mathrm{Bi}-\mathrm{Te}-\mathrm{S}$ minerals, and minor to trace scheelite, consistent with a reduced environment of formation (McCoy and others, 1997). Stannite is present in trace amounts. Gangue minerals include major quartz, very fine- 10 coarse-grained white mica, calcite, and ferroan dolomite. Given this mineralogy, the geochem;cal expression is $\mathrm{Au}-\mathrm{As}-\mathrm{Bi}-\mathrm{Sb}-\mathrm{Te}(\mathrm{Zn}, \mathrm{Cu}, \mathrm{Ag}, \mathrm{B}, \mathrm{Sn}, \mathrm{Be})$.
Skarns and sulfide replacement bodies (table I) are present where carbonate-bearing rocks occur near mineralized Early Cretaceous plutons. Although they commonly contain abundant chalcopyrite, their high Aw/Ag ratios, abundant arsenopyrite. and high Bi contents indicate most are better classified as "gold skarns" than as "copper skarns" (Meinen, 1992; Newbeny and others, 1997). Within the study area there are commonly some gold-bearing veins in the Au-rich skarns, and some small amounts of skam with the pluton-hosted veins/breccias, but the two deposit lypes appear to be largely murually exclusive. Although high-carbonate rocks are the best host rocks, appreciable amounts of skarn are present in units with as little as 10 percent carbonate (for example, TRvs). The largest example is at Silver King (Hawley and Clark. 1974, Newberry and others, 1997) immediately north of the Healy A-6 Quadrangle.

These Au-rich skams contain pyrite, magnetite, chalcopyrite, arsenopyrite \pm pyrthotite as the dominant sulfides; small to trace amounts of bornite. molybdenite. scheelite, and Bi-Te minerals are also present (Newberry.

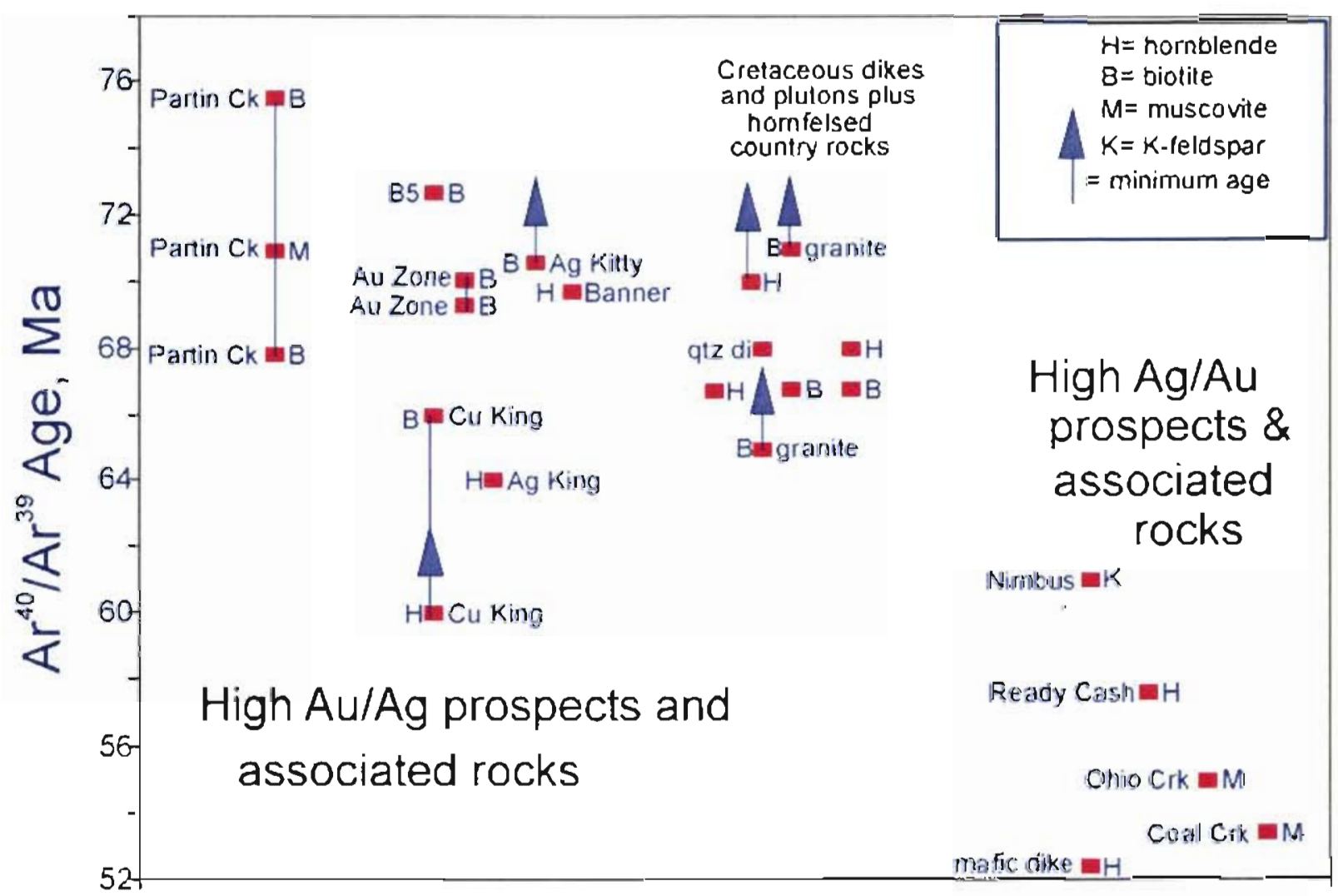

Figure 7. Interpreled "Arf"st ages for mineralized and related rocks in the Chulimes region, laken from table f. Verlical arrow:s designate age from highest-lemperature Ar fraction and indicale minimum age; all other ages are from "

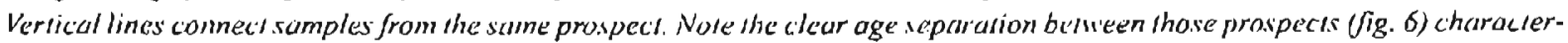

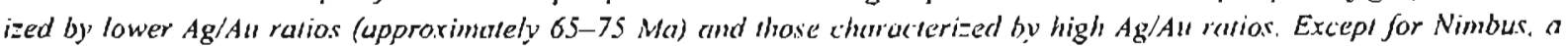
weakly mineralized porphyry Mo prospect of uncertain age. the high Ag/Au deposis' all comain appreciable Sn. Dasa fiom this' study. 
1995). The most common gangue minerals are low-Fe garnet. high-Fe clinopyroxene, homblende, calcite, and quartz. The geochemical signature for these deposits is: $\mathrm{Cu}-\mathrm{Ag}-\mathrm{Au}-\mathrm{Bi}-\mathrm{As}-\mathrm{Sb}-\mathrm{T} \mathrm{c}-(\mathrm{Mo}-\mathrm{W}-\mathrm{U}-\mathrm{Be}-\mathrm{Co}-\mathrm{Ni})$.

Known Ag-rich prospecls associaled with early Terliary granites in the study region (table 1 ) are of rwo basic varieties: (1) vein/veinlei-dominated mineralizalion located outside of the parent grante body and (2) granite-hosted greisen deposits. The laner are lurge. bulkconnage deposits of near-economic potential (Kurtak and others, 1992); the former appear to be "distal" signals of deeper, and larger mineralized plutons. The best examples of polymetallic, Sn-bearing veins and sulfide replacements are present at the Ready Cash prospece (Hawley and Clark, 1974): lower-grade $\mathrm{Sn}-\mathrm{Ag}$ mineralization associated with toumaline breccias at Lookout Mountain probably has a similar origin. The ore mineralogy includes cassutente and stannıte, najor arsenopyrite, sphalerite. gálena, pyrite, and chalcopyrite, and minor wolframite. stibnite. bismuthinite. and argenite. The gcochemical expression is $\mathrm{Ag}-\mathrm{As}-\mathrm{Sn}-$ $\mathrm{Zn}-\mathrm{Cu}-\mathrm{Pb}-\mathrm{Bi}-\mathrm{W}-\mathrm{Rb}-\mathrm{B}-\mathrm{Be}-\mathrm{F}-\mathrm{Li}-\mathrm{Ga}$.

Tin greisen deposits are known in upper Ohio Creek in the A-6 quadrangle, and just south of the A-6 in upper Coal Creek. The Coal Creek deposil has been extensively diamond drilled and contains identified Sn-Ag-Zn resources. The Ohio Creek prospeci lies within Denali National Park and has nol been drilled, but has been extensively sampled (Wamer and Dahlin, 1989). The ore minerals at both deposits include cassiterite and stannite, major arsenopyrite, sphalerite, pyrite, and chalcopyrite. and minor wolframile, galena. stibnite, bismuthinite, and argentite. Arsenopyrite and stannite-sphalerite geothermometry for the Coal Creek deposit indicite high $\left(>400^{\circ} \mathrm{C}\right)$ temperatures of formation (Parker. 1991). Quanz, fluorite, topaz, and Li-rich while mica are common accessories; tourmaline is variably present. Minor $\mathrm{Zn}-\mathrm{Pb}-\mathrm{Ag}$ skarn is present in rare calcareous rocks near the Coal Creek prospects. The geochemical expression is $\mathrm{Ag}-\mathrm{Pb}-\mathrm{Sn}-\mathrm{Zn}-\mathrm{Cu}-\mathrm{As}-\mathrm{Bi}-\mathrm{W}-\mathrm{Rb}-\mathrm{B}-\mathrm{Be}-\mathrm{F}-\mathrm{Li}-\mathrm{Ga}$.

The Copper King and Nimbus prospecis (table I) appear to be slight vartations on the major deposit types present in the study area. Both are distinguished by conlaining porphyry-lextured felsic intrusive rocks with some slockwork quarzz veining. At the Copper King prospect the majority of mineralization occurs in homfels and rare skami (developed from unit TRvs) as high-grade chalcopyrite-pyrnhotite-bornite masses. The high $\mathrm{Cu}$ and low As contents of this deposit (Hawley and Clark. 1974; Gage and others, 1998) also distinguish it from the other $\mathrm{Au}$ bearing skams in the region. Based on its metallogeny and associations, it is bener classified as a Au-rich copper skam (Newberry and others, 1997) and consequently the associated altered. Cu-bearing granito porplyry inurusion as a porphyry copper prospect. Variations in interpreted ${ }^{40} \mathrm{Ar} /{ }^{30} \mathrm{Ar}$ dates from this prospect (table 2. (ig. 7) indicate themal reselling by younger inmusions. and there may be multiple mineralization events present.

The Nimbus prospect, north of the Healy A-6 Quadrangle, lies wulhin Denali National Park and has not been well srudied. Swainbank and orhers (1977) describe it as a porphyry copper prospect, but molybdenite is more obviously abundant than any copper minerals and $M_{0}$ is present in more anomalous abundance than is $\mathrm{Cu}$ (Gage and others, 1998). Mineralization is confined to altered, felsic porphyry dikes, which locally constitute a dikc swam (Swainbank and oithers, 1977). The exposed rocks associated with mineralization are 100 weathered and altered for reliable chemical analyses or dating and the nearby, less-altered dikes display ambiguous composilional characleristics. Some of these dikes possess composisions similar to demonsitably Cretaceous granites. olhers 10 denonstrably early Teniary granites of the region. Daring of $\mathrm{K}$-feldspar from a less-altered felsic dike yielded a pluteau age of $61 \mathrm{Ma}$-intermediate in age berween the two major types. Most likely this intermediate age indicates the presence of bolh Late Crciaccous and early Tertiary igneous activity. Due to the elevaied Mo and $\mathrm{Ag}$ concentrations of the known mineralization (Gage and others. 1998). we categorize the bulk of hydrothermal activity as distally (?) related 10 a porphyry Mo system.

\section{COMPOSITIONAL CHARACTERISTICS OF MAJOR IGNEOUS UNITS}

All of the exposed volcanic rocks in the study area have experienced al leasi modest degrees of melamorphism. and although original textural features are sonterines preserved, the rocks are best described as "nielavolcanic'. Neither zeolites, prehnile, nor pumpellyste have been observed in these rocks and the minerals aclinolite. chlorite. epidote. and calcite are nearly ubiquilous. Plagioclase is invariably altered to albite and original clinopytoxene grains are variably altered to fine-grained actinolite-bearing assemblages. The metamorhic mineralogy and lack of complete destruclion of original igneous minerals indicales these rocks bave experienced midgreenschist facies metamorphism. The timing and number of metamorphic events experienced, however, is nol presenly interpretable.

Metamorphosed volcanic rocks rarely contain fossils and radiomerric nethods typically fail to penerrate through the metamorphism. Metavolcanic rocks are also notoriously variable in appearance and commonly display as much intra-unil as inter-unit variarion in physical appearance. Consequently, reliable idenrification and correlation of such rocks necessarily requires characteristics that manscend variability in volcanic and metamorphic conditions. The chemical compositions of such rocks, especially with regard to relatively immobile (insoluble) elements have been documented as panicularly valuable 
in such identification and correlation (Pearce and Cann, 1973: Winchester and Floyd: 1977). Because the inetavolcanic rocks of the map area have been previously identified and correlated based exclusively on hand-specimen appearance, and because there is considerable disagreement in the literature concerning the aye, nature, and correlation of these rocks, we used compositional data to help make unit distinetions and correlations. We present this data here to clarify the origins and characteristics of the igneous rocks of the map area.

Most of the metavolmanic and many of the intrusive rocks of the map area are 100 altered for reliable categorization by standard major oxide compositional discriminants such as silica versus alkali diagrams. Gross compositions are better illustrated using 'immobile' element diagrans such as anhydrous normalized $\mathrm{SiO}_{2}$ versus $\mathrm{Zr} / \mathrm{Ti}$ (fig. 8). On such diagrams, the Paleozoic metavolcanic rocks (' $D$ ', 'bp'. 'd', and 'ut', fig. 8A) display a compositional range from subalkali basalt to rhyodacite/dacite, the 'average" composition of Devonian metavoleanic rocks within the andesite field and the average for upper Paleozoic uff in dacite/rhyodacite. Red colored clastic rocks, previously described as 'redbeds' (Jones and others, 1980) display a compositional range from basalt 10 dacite with most analyses of andesitic composition (' $r$ '. fig. 8A). Late Triassic metavolcanic rocks, herein correlated with the Late Triassic 'Wrangellia' flood basalts, in contrast, yields strictly basaltic compositions ( $\mathrm{N}$ ', fig. $8 \mathrm{~A}$ ).

In contrast, intrusive rocks of the study area comprise two generally distinguishable groups (fig. 8b): older (Late Cretaceous) rocks of intermediate 10 felsic compositions (' $k$ ', fig. 8b) and early Tertiary rocks characterized by bimodal felsic and mafic compositions (' $z$ ' and ' $T$ ', respectively, fig. 8b).

That metamorphosed rocks possess elemental characteristics compatible with an igneous origin does not prove they are of igneous origin. The most controversial metamorphic rocks of the study area are the so-called 'redbeds', which possess a generally red color and characteristically clastic textures, but lack definitive evidence for sedimentary origins, such as fossils or sedimentary structures. Thin-section examination shows these rocks contain linte quartz; major oxide chemical analyses (fig. 9A) show that they possess $\mathrm{SiO}_{2}$ contents well below that of sandstone (even graywacke) but compatible with intermediate-mafic igneous rocks. as previously described (fig. 8A). Other compositional criteria. used both to identify sandstones and to identify their tectonic environments (fig. 9B) show that the red clastic rocks of the map area in general do not overlap compositionally witt uny sandstones of any tectonic seting, but again overlap compositionally with intermediate-mafic igneous rocks. It is hard to avoid the conclusion that, for the most pan, these variably clasric red-colored rocks are primarily not continental sandstones.
A final means to compare the basaltic members of the different units is in terms of their relarive $\mathrm{Ti}, \mathrm{Zr}$, and $\mathrm{Y}$ concentrations (fig. 10), which can also be used 10 infer tectonic environment of formation. Notably. Late Triassic volcanic rocks inferred to be stratigraphically equivalent 10 the Nikolai basalt of Wrangellia display immobile element ratios consistent with a 'within-plate' setting, compatıble with the rift or mantle plume seming for Nikolai inferred by other workers (Barker and others, 1989; Richards and olhers. 1991; Plafker and Berg, 1994). Similarly, the early Teriary mafic rocks (' $T$ ', fig. 10B) display 'within-plate' characler, compatible with the bimodal (felsic + malic) compositions (fig. 8B) of these rocks, a characteristic of extensional-related igneous systems.

Compositional comparisons between melavolcanic rocks of the study area and potential stratigraphic equivalents outside of the region (iig. 1I) shows that some age-similar units arc potential marches and others are not. The Triassic (Ladinian-Carnian) basaltic rocks of 'Stikinia", west-central Yukon, are sufficiently close in lime to the Late Triassic (Norian) volcanic rocks of the study area to invite correlation. As shown by figure IIA. however, the strong contrast in immobile trace element contents of the two units rules out such a correlation. In contrast. immobile trace element compositions of Late Triassic Wrangellia basaltes fall witlin the compositional range of the age-equivalent rocks in the study area, indicating a correlation is permissible. Similarly. the compositional similarities berween late Paleozoic to early Triassic Skolai volcanic rocks and those of the early Triassic (and older?) red volcanic/volcaniclascic rocks of the study area invite a correlation between the two.

The Late Cretaceous and early Tertiary igneous rocks of the study area are primarly of intrusive character and consequently more easily distinguished based on handspecimen characteristics. For example. Hawley and Clark (1974) suggested that the older (now known to be Late Cretaceous) incrusions were generally less felsic and the younger (now known to be early Teriary) intrusions were more felsic. Such an assertion is demonstrated by figure $8 \mathrm{~B}$, based in par on immobile element ratios, but also by compositional classificalion employing nomative major oxide compositions (fig. 12A). Although some strongly altered Cretaceous rocks (denoted by ' $k$ ') fall outside the general compositional fields. the bulk of analyses display a unimodal variation from quartz diorite and monzodionite to syeno-granite, suggesting a fractionation-related assemblage. The normative quartz contents vary from 0 to greater than 20 percent, and on the whole increase with increasing nomative onhoclase/anonhite ratio, again suggesting a coherent fractionation assemblage. In contrast. the early Tertiary igneous rocks display strikingly bimodal compositions, dominated by basalugabbro + alkali-feldspar granite and lesser syeno-granite. 
A

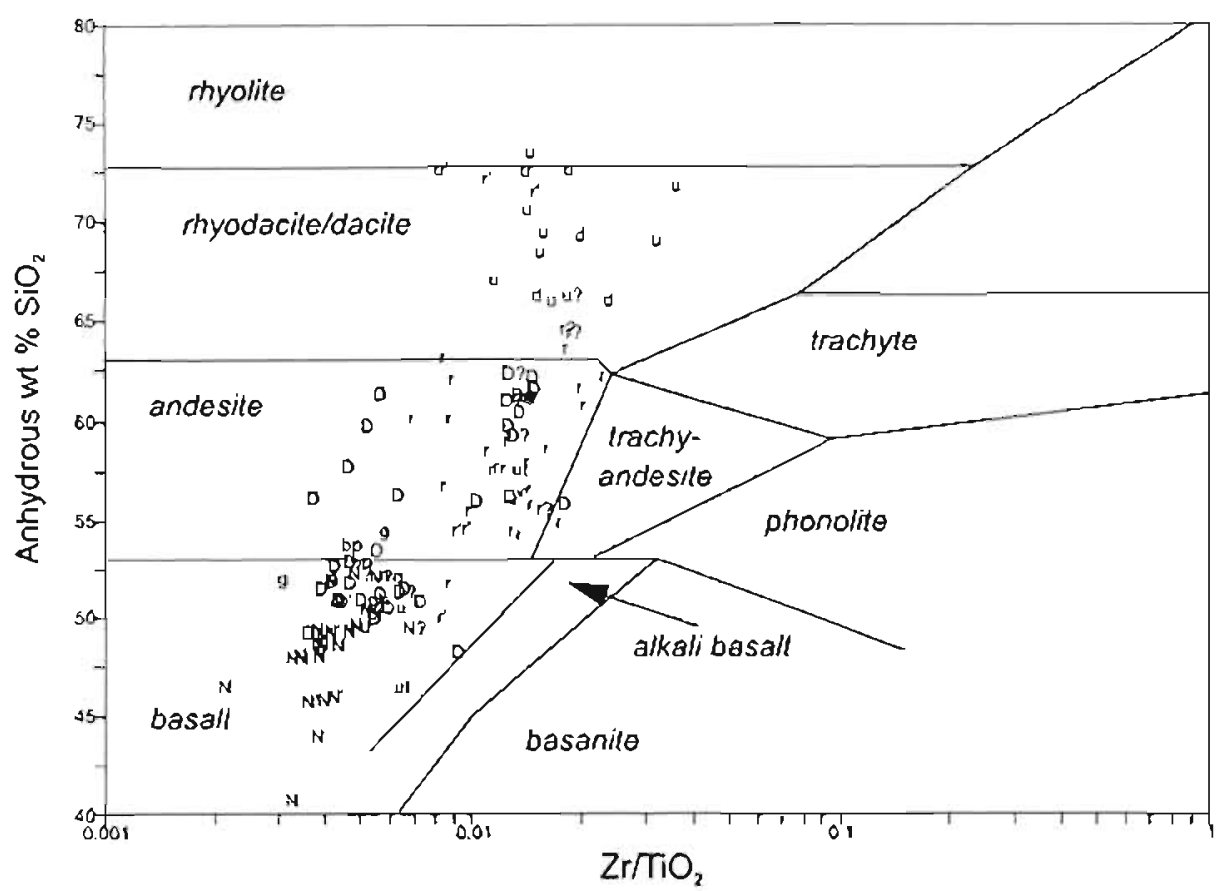

B

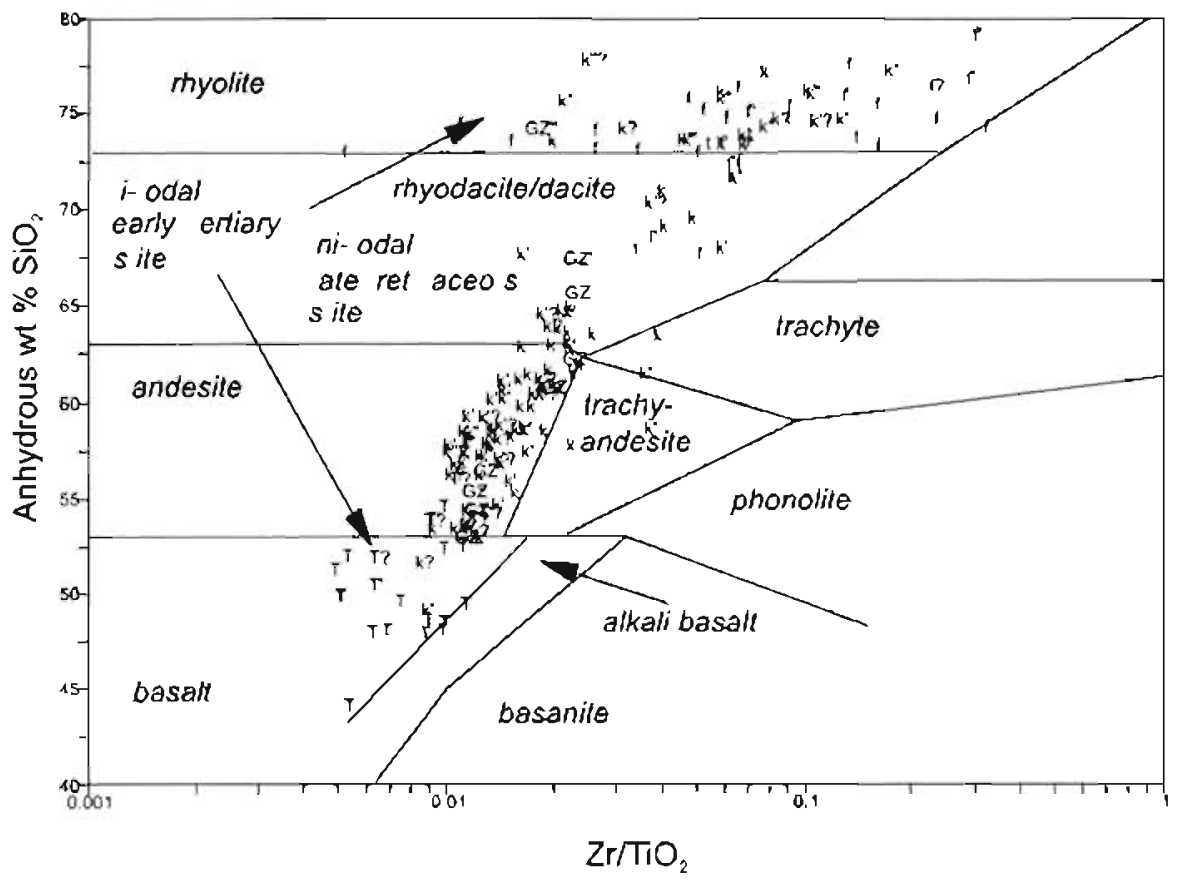

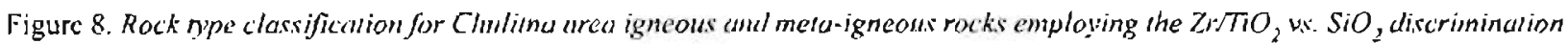
dugrem of Win heser and Flovd (1977). Symbol modifiers: "= mineralogv indicules chemicul alleratian: " = highb' whered:

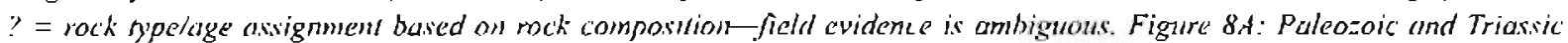

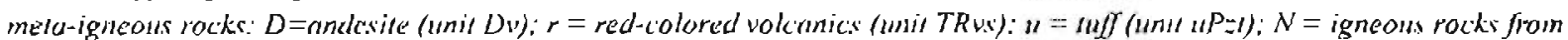

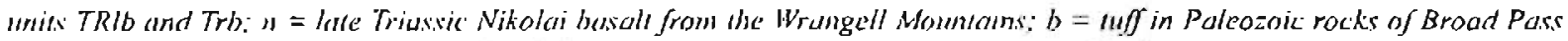

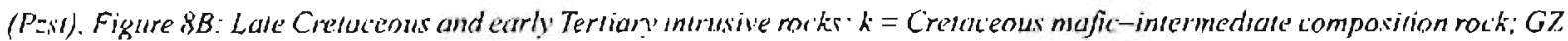

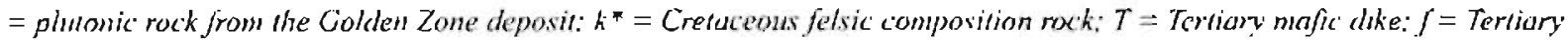
fekic imrusion. Daro from Hawley and Clark (1974). Dorwis and Plafker (1985). Balen (1990). Burker ond ofhers (1994). Newhery and Solie (1995), and Guge and olhers (1998) 
A

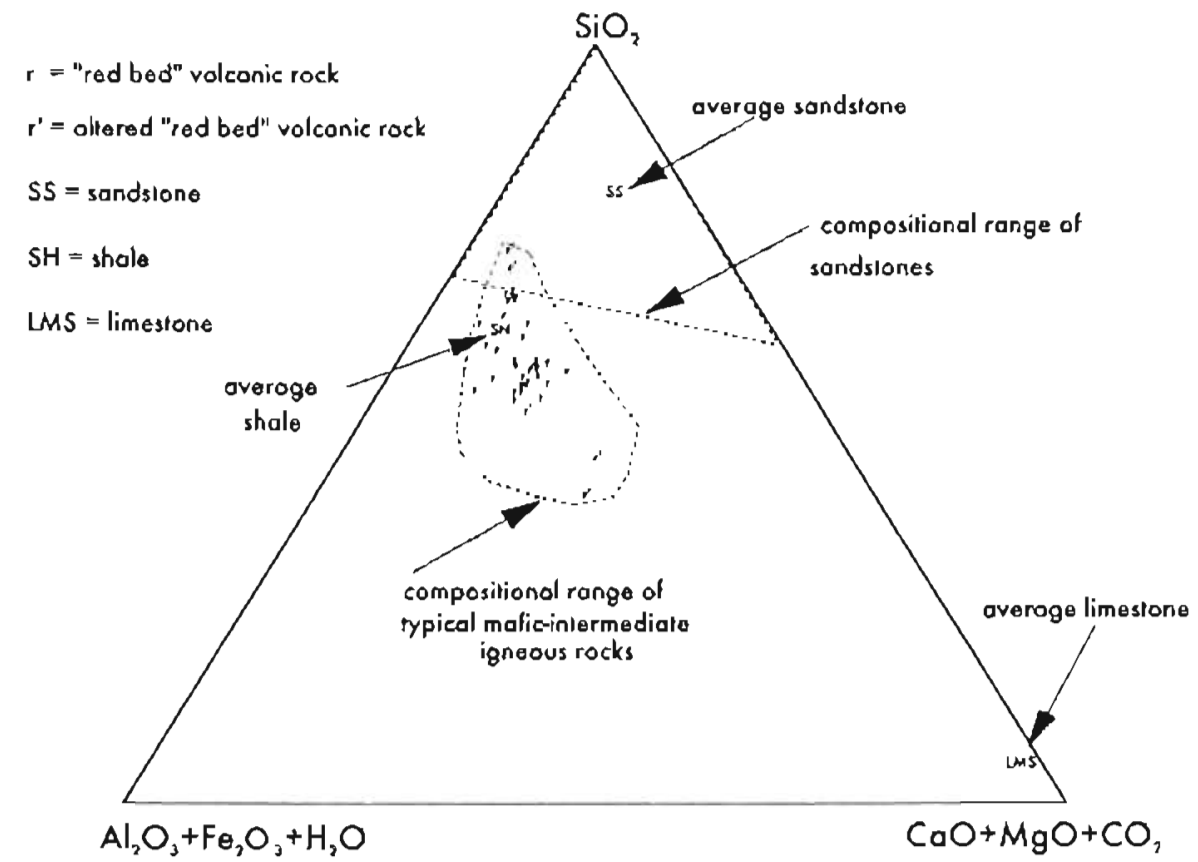

B

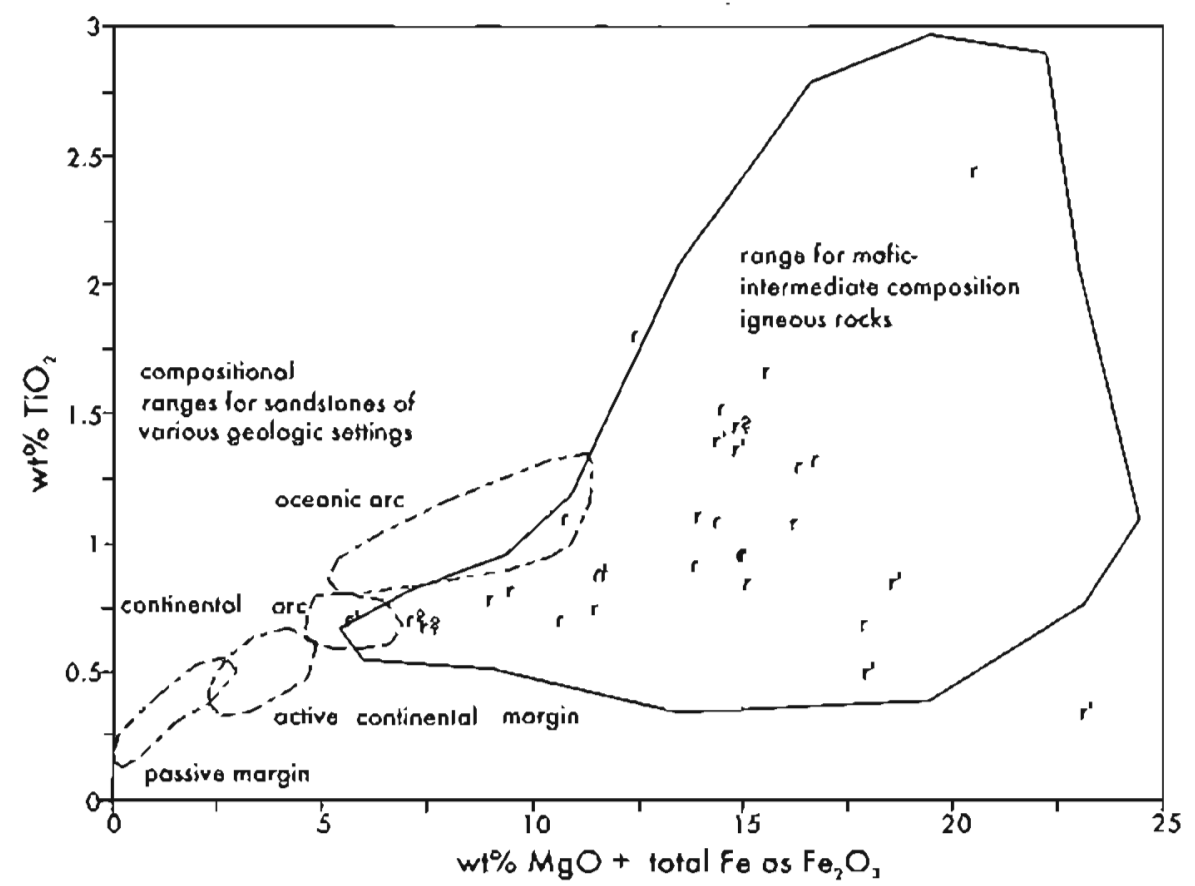

Figure 9. Major elemens compositions of red clavic rockir ('redbeds') of the study area compared to those for sandstones and inoficintermediate zomposinion igneous rocks. Figule. 9A. Major element ralio diagran. modified from Maran (1966), showing that red clavic moks of the shidy area do not compositionally revemble sandstones. bu do resemble mafic-imermedhale composition igneous rocks (and some shales). Figure. 9B. Major elemen-based lectonic clasification scheme for sandsponer (from Bhuta. 1983) showing compositions of clastic red meki from the shutly area and range for (ypical mafic-intermediale composition igneous rock: 


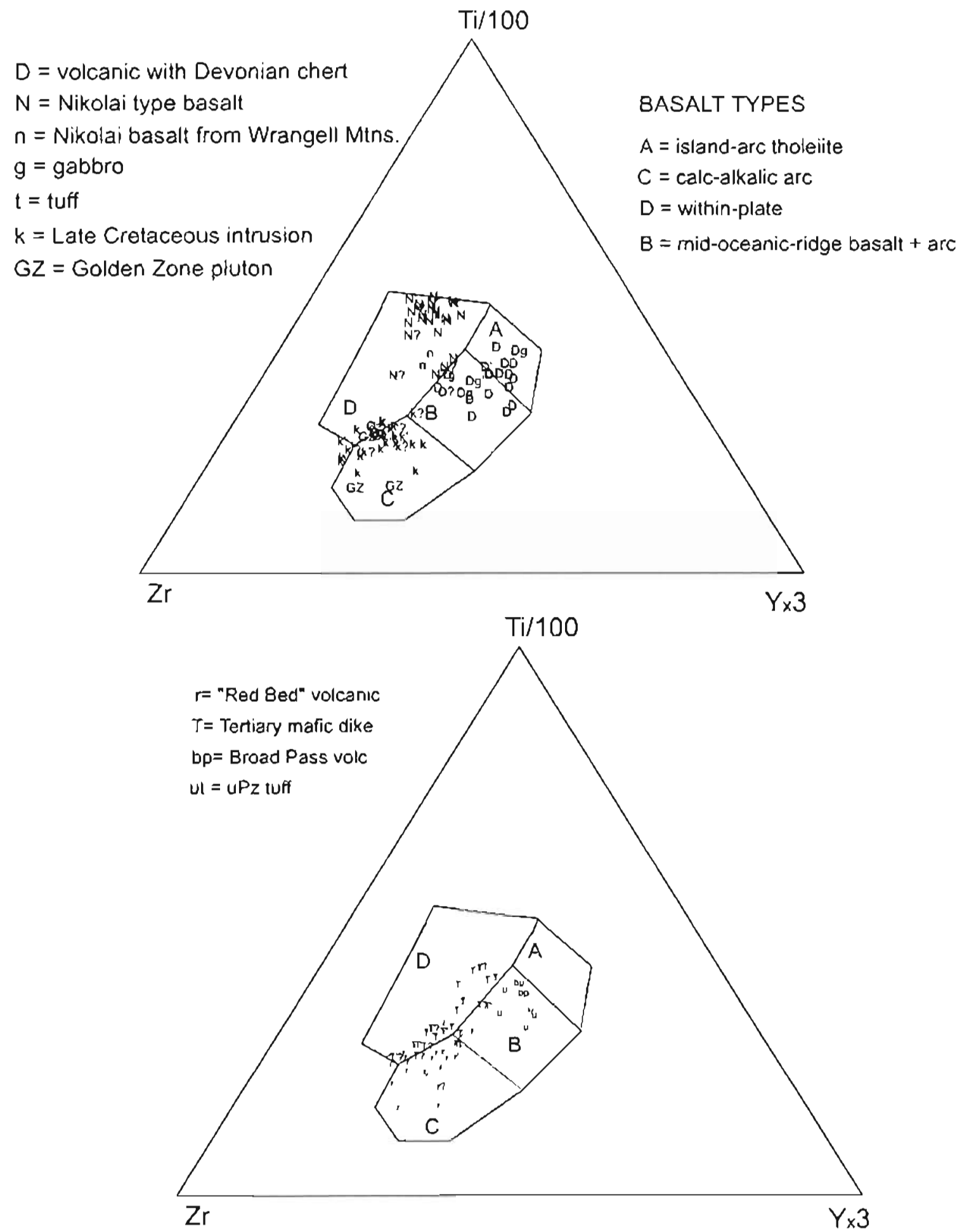

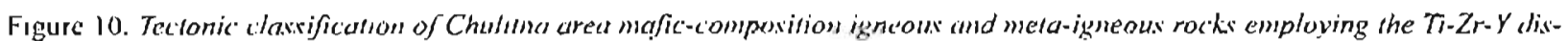
crimination diagrum of Pearce and Canm (1973). Figure 1/A Mafic rock comipaxitions from unik TRlb. Trb. Dv. and Kn.

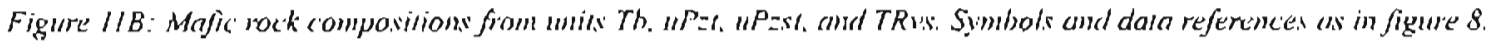



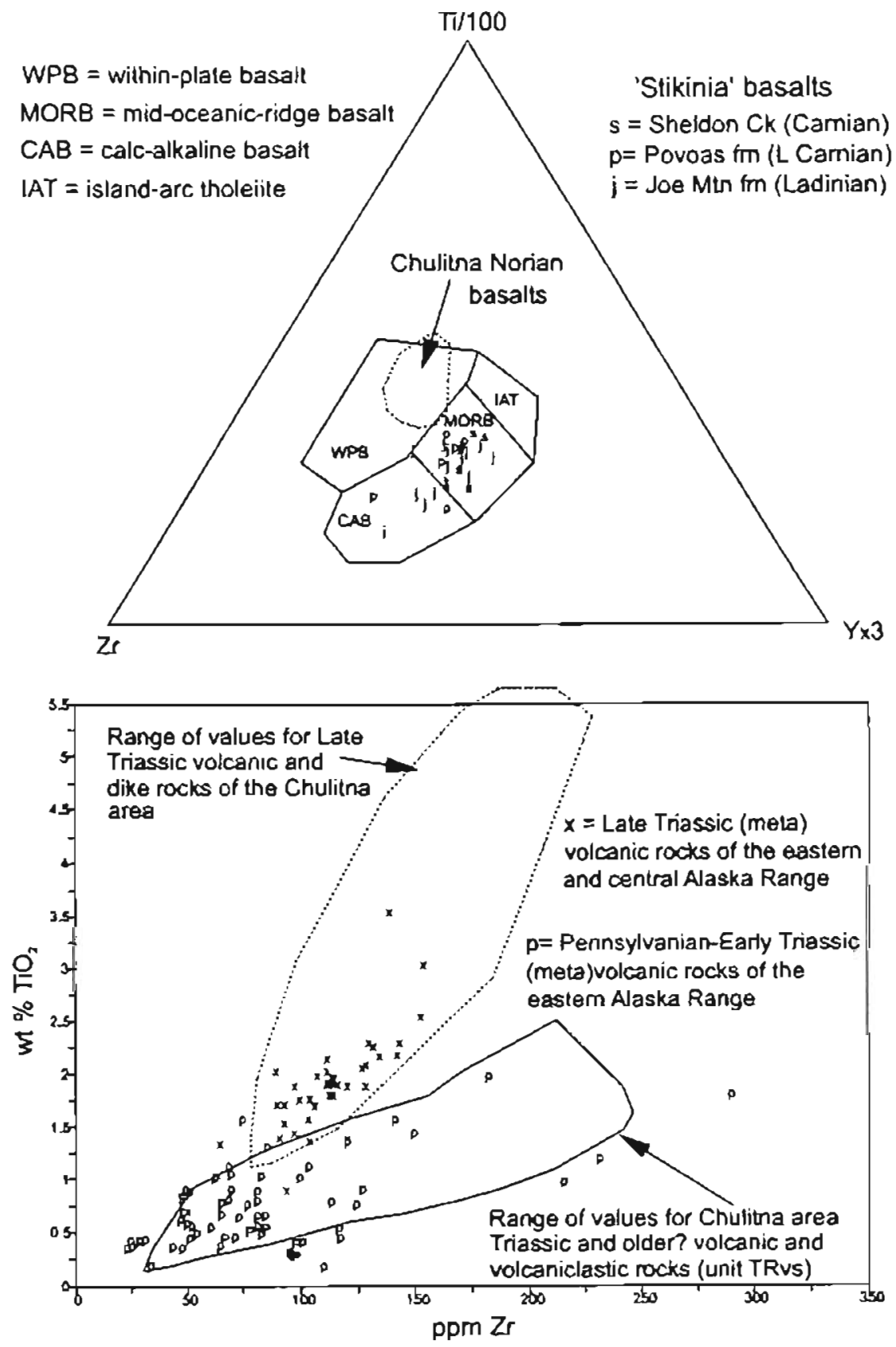

Figure 11. Immobile element comparisons between lale Paleozoic and Triassic melovolcanic rocks of the study area and polentially equivalent unirs from southern Alaska and eartern Yukon Territony. Dasa from Beard and Barker (1989). Barker and others (1994). Hars (1997). Athey (1999), and Gage and athers (1998). Figure 11 A. Y-Zr-Ti lernary diagram showing controsi beiween Triasric basalts of the "Sikinia "rerrane. Yukon Territory, and those of the study area. Although broadly similar in age (LandinianCarnian vs. Norian) the compositional differences indicate that the Stikinia basals are not equivalent to the "within-plate" basalus of the srudy area. Figure $/ 1 B$. Zr-Ti plor showing similarity in comparitions of (I) Skolai arc volcanic/volcaniclastic rocks of southem Alaska with Early Triarsic volcanictvolcaniclastic rocks of the study area, and (2) Late Triassic 'Wrangellia' flood basall of southem Alasko and Late Triassic basall of the study area. 

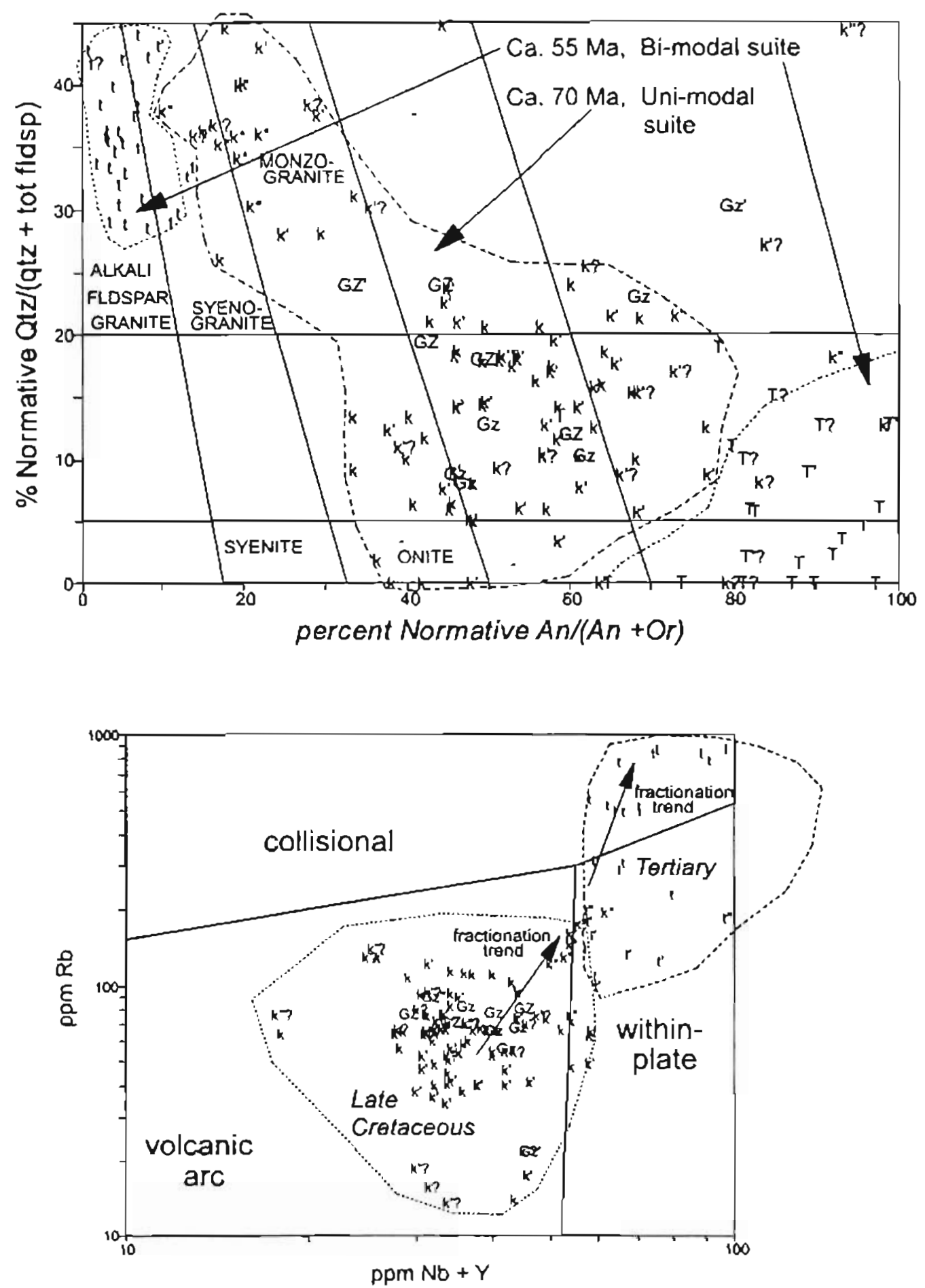

Figure 12. Compositional characteristics of Late Crelaceous and early Tertiary inirusive rocks of the study area. Symbols: $k=$ Late Cretaceour mafic-1mentediale rack, $k^{*}=$ Lale Crefaceous felsic rock: $t=$ early Tertiary felsic rock: $T=$ early Tertiany mafic rack. '= chemically altered, " = very aitered, $?=$ age aisignmens based on rock composition-field relationships are ambiguous. Dala from Howley and Clark (1974). Warner and Dahlin (1989). Balen (1990), Parker (1991), Gage and others (1998). and this s/udy. Figure I2A. Nomasive rock type classification diagram, after Streckeisen and LeMaitre (1979). Figure 12B. Rb. $\mathrm{Nb}$ and $\mathrm{Y}$ data from Chulitna area Cretaceous and Tertiary intrusive rocks plotied on the granitoid lectonic setting diagram of Pearce and oihers (1984). 
Minor element compositions of the intrusive rocks confirm differences in geologic setting accompanying the major element differences. A conventional means of identifying differences in tectonic environment of formation is through $\mathrm{Rb}$ vs. $\mathrm{Nb}+\mathrm{Y}$ (fig. $12 \mathrm{~B}$ ), which cannot be employed for the metavolcanic rocks because $R b$ is highly mobile during metamorphism. The unmetanorphosed and generally weakly altered Late Cretaceous and early Tertiary rocks, however, define two compositional ficlds with little overlap (fig. 12B). The older intrusive rocks display a "volcanic arc' signature whereas the younger intrusions display 'within plate" or 'collisional' signatures. Because $\mathrm{Rb}$ is known to increase with fractionation (Pearce and others, 1984) as shown by the arrows on figure 12B. the lower-Rb members of each suite are bener indicators of the tectonic environment, thus, a 'within-plate' setting is more likely for the early Teriary felsic rocks. This interpretalion matches the trace element signature of the mafic early Tertiary rocks. Such a bimodal suite is conventionally explained by intrusion of basaltic magma into the lower crust, the anomalous heat causing partial melting and farmation of the felsic melts.

Based on these compositional characteristics, we suggest the following changes in stratigraphic and tectonic interpretations for the metavolcanic rocks of the Chulitna region.

1. While we recognize some sedimentary rocks with in the Chulitna region, much of what was previously mapped as 'redbeds' (oxidized, continental, wamiclimate sandstone) is better described as a red volcanic wacke that compositionally resembles calc-alkaline arc volcanic rock. We have created two units from the 'Late Triassic continental redbeds' of Jones and others: (a) an older, largely volcaniclastic and volcanic portion that may extend into the Permian. but is at least as old as lower
Triassic and (b) a younger, Late Triassic, commonly white quartz conglomcrate that may interfinger with a fossiliferous. near-shore, marine calc-sandstone. Boih members broadly resemble the upper Paleozoic to lower Triassic marine sedimentary and andesitic volcanic unit observed below the Nikolai basalt in the so-called 'Tangle suberrane' of Nokleberg and olhers (1994).

2. Trace-elemene chemistry of Triassic basalt in the Chulitna region correlates with that of extensional Late Triassic Nikolai greenstone mapped throughout southern Alaska and contrasts strongly with Stikinia terrane rocks of similar agc. Consequently, the limestone-basalt unst in the Chulitna region is best described as a variant of the Wrangellia Nikolai basalt.

3. Volcanic rocks spatially associated with Late Devonian chert and-locally-with serpentinite fault slivers (our unit Dv) have the chemical characteristics of volcanic arc-related igneous rocks and are neither mafic/ultramafic dominated nor possess MORB-like compositions. We thus reject the suggestions of Jones and others (1981) that this sequence is an ophiolite and that it is a unique rock package in southcentral Alaska.

4. Devonian volcanics (our unit Dv) and iuffs (our units uPzt, uPzsi) in the previously mapped West Fork and Broad Pass terranes (Jones and olhers. 1981) may be the same lime-stratigraphic unit.

5. In summary, our evidence contradicts the asserion that Chulima is a 'unique tertane' (Jones and others, 1981). but is compatible with the hypothesis that it represents a variant of the Wrangellia terrane of eastem Alaska. We believe it comprises a conposite of Chulitna, West Fork, and Broad Pass terranes (Jones and others, 1981) of earlier usage.

\section{DESCRIPTION OF MAP UNITS UNCONSOLIDATED DEPOSITS}

This map illustrates the distribution of a variety of unconsolidated deposits in the Chulitna mining district. It was prepared by the interpretation of 1:63,360-scale, false-color, infrared aerial photographs taken from July 1980 through July 1982 and is only locally verified by ground observations during brief field visits. The results should be considered reconnaissance in nature.

Terms used to describe the estimated percentages of cobbles and boulders are 'numerous', 'scanered', and 'rare." 'Numerous' implies that drilling through the layer would encounter two cobbles or boulders in an interval of $0.6 \mathrm{~m}$; "scattered' implies that drilling would encounter two cobbles or boulders in an interval of 3 $104.5 \mathrm{~m}$; and 'rare' implies that drilling would encounter two cobbles or boulders in an interval of more than $4.5 \mathrm{~m}$.

Estimated content of sand and silt, based on field observations, is indicated by the tenns 'some' and 'trace." 'Some' implies a general composition of 12 to 30 percent. 'Trace' implies a general composition of 4 10 12 percent. Estimated compositions less than 4 percent were not recorded in the field. 


\section{Alluvial Deposits}

Qa UNDIFFERENTIATED STREAM ALLUVIUM - Elongate deposits of moderately- to well-sonted, wellstratitied, fluvial pebble-cobble gravel, sand, and silt, with rare to numerous boulders, deposited in active stream channels. hoodplains, and associated low terraces. Deposit is medium to thick bedded, locally crossbedded, and shows fining-upward cycles. Clasts generilly counded and boulders reach a maximum dianteter of I $\mathrm{m}$. Exitensive willow-alder thickets grow on many Qa deposits in mature valley fills. Surface smooth except for local low scarps.

Qac ABANDONED-CHANNEL DEPOSITS - Elongate variable deposits in channels of former nel rwater streans nol related to modern stream regimens and subsequent underfil streams. Composition ranges from slightly washed drift with thin. local surface lags of cobbles and boulders to well-soned. elean pebble-cobble gravel and gravelly medium to coarse sand with rare to numerous boulders: thin to thick bedded. locally crossbedded. Surface simooth with local low scarps and bogs.

Qaf ALLUVIAL FAN DEPOSITS - Fan-shaped, heterogeneous mixtures of poorly 10 moderately sorted, parlially stratified. channelized gravel with some sand and silt and scattered to numerous. subangular to rounded boulders. especially in proximal areas. Clasts locally derived. May include torrential fluvial deposits and debris-flow deposits. Thick 10 thin bedded. Generally localized at intersection of first and second order (uibulary and trunk) streams. Surface smooth except for numerous shallow. interconnected channels.

Qat TERRACE ALLUVIUM - Elongate deposits of well-sorted. well-rounded to subrounded pebble-cobble gravel and sand with trace to some silt and rare to nume rous boulders up to $50 \mathrm{~cm}$ diameter comprising stream terraces bordenng modern floodplains and clearly related to modem drainage: includes strath terraces. Surface smooth except for local low scarps.

Qfp FLOODPLAIN ALLUVIUM - Elongate deposits of moderately- to well-soned, well-stratified. fluvial gravel. sand, and silt with scattered to numerous boulders forming modem floodplains and associated low terraces. Typically mantled by thin layer of silty overbank deposits. Generally finer grained than similar deposits in Qa unit because of deposition during floods. May locally include Wisconsin to Holocene terrace alluvium. Surfaces are flooded during periods of high stream discharge. Highly variable thickness difficult to estimate due to poor exposure. Surface sinooth to hummocky with local low scarps and bogs.

\section{Colluvial Deposits}

Qc UNDIFFERENTIATED COLLUVIUM - Irregular, heterogeneous blankets, aprons, and fans of angular to subrounded rock fragments, gravel, sand, and sill that are left on slopes, slope bases, or high-level surfaces by residual weathering and complex mass-movement processes, including rolling, sliding, flowing, gelifluction, and frost creep. May include greatly modified driti of older glaciations. Locally washed by meltwater and slope runoff. Mediun to thick bedded; thickness highly variable. Surlace smooth. lobed. or terraced and generally reflects configuration of underlying bedrock surface.

QcI LANDSLIDE DEPOSITS - Oval- to longue-shaped heterogeneous mixtures of fractured bedrock and pebblecobble gravel with trace 10 some sand and silt deposited by near-surface to deep creep, that is, flowing and sliding due to instability of failed bedrock and unconsolidated surficial deposits. May be block-supported, especially near the surface. Surface ranges from slightly imegular and broken by arcuate ground cracks and low ridges, to hummocky and covered with jumbled. openwork rubble with individual angular to subangular blocks up to $15 \mathrm{~m}$ diameter.

Qct TALUS AND RUBBLE DEPOSITS - I blocks are common), heterogeneous, angular rock fragments and rubble with trace to some silt, sand, and gravel deposited more or less in place on steep upper slopes and at the mouths of steep bedrock couloirs by block weathering. frost riving, snow avalanches, free fall, tumbling, rolling, and sliding. Deposits are widely subjected to secondary reworking by cryonurbation. including frost heave and frost jacking of rock fragments. Surface steep, irregular, generally unvegetated, covered with numerous angulatr rock fragments, and characterized by openwork nubble mounds many meters thick.

Qrg ROCK-GLACIER DEPOSITS - Tongue- and fan-shaped heterogeneous mixnures of angular to subangular blocks of local bedrock and ice with trace to some gravel, sand, and silt at depth that accumulate on floors and lower walls of cirques by flow of rock glaciers derived from shrinking of former glaciess (ice cored) or from deposition and cementation of precipitation-derived ground ice (ice cemented). Perennially frozen where aclive. Probabily generally clast-supported. Surface furrowed. concentrically ridged, pirted, or hummocky and covered with angular 10 subangular blocks up to $2 \mathrm{~m}$ in diameter: generally unvegetated, but locally overgrown with moss, lichen, and some grass on inactive and less aclive rock glaciers. 


\section{Paluulal Deposits}

Qs SWAMP DEPOSITS - Elongate to blanket deposits of complexly bedded peat, organic silt, and organic sand accumulated as surface deposits in local basins and in former stream channeis. Saturated and locally frozen, locally ice rich. Thickness highly variable. Surface sinooth, ridged, mounded, hummocky, or pined. May have standing water.

\section{Glacial Deposits}

Qao OUTWASH ALLUVIUM - Elongate to han-shaped heterogeneous mixture of washed, rounded to subrounded pebble-cobble gravel with some sand and silt and scattered to numerous subangular to rounded boulders deposited by meitwater streams draining margins of former glaciers. Thin to thick bedded. locally crossbedded. Surface generally smooth and gently sloping, except for local low scams

Qt2 TILL OF LATEST HOLOCENE AGE - Helerogeneous mounds and ridges of pebble-cobble gravel, sand, silt, and clay in varying proportions deposited at or near the margins of modern glacial ice or where glacial ice has existed until very recently: contains rare to numerous large ( $2 \mathrm{ni}$ diameter and greater) boulders. May be ice cored. Surface hummocky with numerous scattered boulders and generally retains primary morainal morphology; little or no vegetative cover or soil development.

Qt1 TILL OF EARLY TO MIDDLE HOLOCENE AGE - Heterogeneous mounds and ridges of pebble-cobble gravel, sand, silt, and clay in varying proportions deposited direclly from glacial ice; contains rare to numerous large (2 $\mathrm{m}$ diameter and greater) boulders. Surface hummocky with numerous scattered boulders and generally retains primary morainal morphology: nominal soil development with well-established vegetation consisting primarily of lichen. moss, and herbs.

Qd DRIFT OF LATE WISCONSIN AGE - Heterogeneous blankel of pebble-cobble gravel, sand, silt, and clay in varying proportions deposited by glaciers; contains rare to numerous large ( $2 \mathrm{~m}$ diameter and greater) boulders deposited directly from glacial ice. Soring, bedding, and clast roundness highly variable, depending on degree of water reworking. Deposit locally includes or is gradational with ourwash. Clay-rich diamictons may form high, steep slopes where incised by streams and are subject to earthflows when sarurated. Locally forms steep-sided, sinuous ridges (eskers) up $1012 \mathrm{~m}$ high and $4-5 \mathrm{~m}$ wide at the crest. Thickness ranges from a thin and patchy veneer over ice-scoured bedrock to more than $25 \mathrm{~m}$ thick. Typically overlain by up to $1 \mathrm{~m}$ windblown silt. Surface smooth to highly irregular with local bogs and ponds. Based on geomorphological relationships, deposit is probably correlative with deposits of the last part of the Riley Creek glaciation in the Nenana River valley on the north side of the Alaska Range (Wahrhaflig, 1958), and deposits of the Elmendorf stade of the Naptowne glaciation in the Cook Inlet region (Reger and Pinney, 1996). The latter part of the Riley Creek glaciation has been dated to approximately 9,500-12.800 yr. B.P. (Ten Brink, 1983), and the Elmendorf stade dates to approximately 9,500-14,000 yr B.P. (Reger and Pinney, 1996).

\section{Complex Deposits}

Qef COLLUVLAL-ALLUVIAL VALLEY FILL, FAN, AND APRON DEPOSITS - Elongate, apron- and fanshaped, heterogeneous mixtures of poorly 10 moderately sorted angular rock fragments with trace 10 some gravel, sand, and silt of fuvial and colluvial origin deposited at the bases of steep slopes bordering modern stream valley courses and at the mouths of bedrock couloirs and gullies. Deposited primarily by debris flows and brief, intense (torrential) summer stream flows. May include snow-avalanche deposits. Commonly forms alternating stratified and unstratified zones and lenses in gullies and steep tributary valleys with intermiment or ephemeral streams. Locally washed by meltwater and slope runoff. Youthful alluvial-colluvial fan deposits are actively being formed or modified when seasonal snowpack is melting. Surface steep ro gently sloping. with local low scaps.

\section{Manmade Deposits}

Qh ARTIFICIAL FILL AND EXCAVATION SITES - Pebble-cobble gravel with trace to some sand and sils forming bases for roads and piled in active or former gravel pits. Well to poorly sonted. Surface smooth to irregular. Extent based primarily on distribution between July 1980 and July 1982 when the aerial photographs were taken. 


\title{
BEDROCK UNITS
}

\section{SEDIMENTARY AND VOLCANIC ROCKS}

\author{
Tertiary deposits
}

Ts GRAVEL AND SAND (Miocene'? to Paleocene") - Orange- to buff-colored, well-sorted, clast-supported. sandy pebble-cobble gravel and sand (sheel I. photo 3). Measured thicknesses of this unit range from 6 to 45 $\mathrm{m}$. The deposit shows varying degrees of orange and purple-black (mangamese oxide) discoloration and weathers to light buff or grayish brown. While typically poorly to moderately consolidated, the unit is locally indurated enough to approach a true conglomerate. The deposil forms bare, near-verucal cliffs where incised by streanis and is prone 10 gullynng. Clasts are sub-rounded to very well rounded, and median clust size is approximately $5 \mathrm{~cm}$ in diameter. The largest cabbles are generally not more than about $15-20 \mathrm{~cm}$ diameter, although can locally exceed $40 \mathrm{~cm}$ diameter. Clast lithology is rypical of an Alaska Range source area, including cher. argillite, gray wacke, volcanic rocks. felsic to intermediate intrusive rocks, and the distinctive conglomerate from the Cantwell Formation (Capps, 1940) with well-rounded clasts of quartz, gray to black chen, sandstone. and argillite. Many of the granitic to dioritic clasts are highly weathered. especially the more mafic ones. The deposit is predominantly massive to thick-bedded, and has an overall horizontal fabric. It is locally very well bedded with crosscutting channels and crossbedding. especially in sind beds and in some pebble beds. Local channeling is most apparent in sandy units. Sand beds typically constirute no more than 2-5 percent of the section, but are locally much more abundant. Sands occur mosily as broad lenses with an average thickness between 10 and $20 \mathrm{~cm}$ and a maximum measured thickness of $80 \mathrm{~cm}$. Silt bodies are very rare, occurting as lenses up $1035 \mathrm{~cm}$ thick that may locally exhibit soft-sediment deformation structures due to loading. Pollen samples collected from the rare silt beds were 100 oxidized to be analyzed. The upper contact of the deposit is erosional, forming a slightly irregular surface that appears to dip to the south. This deposit is fluvial in origin. and was laid down by a very active, sediment-laden stream system that probably developed in association with the uplift of the Alaska Range during Teriary time. This deposit is probably correlative with the Nenana Gravel on the north side of the Alaska Range. This unit is preserved in the downdropped, fault-bounded block, or graben in Broad Pass in the southeastern portion of the map, where it can be observed in exposures up to $100 \mathrm{~m}$ thick.

Tes COAL-BEARING SANDSTONE (Oligocene?) - Poorly to moderately consolidated, light gray to yellow pebbly sandsione and pebble conglomerate with smaller quantities of brown micaceous silty claystone, carbonaceous claystone. and lignite. Lignite seams are dark brown on boch fresh and weathered surfaces and break with a shaly fracture or irregularly along shrinkage cracks. Seams dip less than 10 degrees: are 5 to 10 ft thick and contain 0.2 to 0.4 percent sulfur and 10 10 20 percent ash with a heating value of 5,500 to 7,100 Btu/lb (Hopkins. 195I: Merritt and Hawley, 1986). Thought to be correlative with Oligocene coal-bearing deposits at the Dunkle coal mine on Camp Creek, about ten miles to the west (Csejtey and others, 1992).

\section{KuHILTNa ASSEMRLicis.}

The Kahilina assemblage (Reed and Nelson, 1980, Csejtey and others, 1978, 1982, 1992; Nokleberg and others, 1994 ) is found in the nortitwest and eastern map areas. and may underlie the intervening older rocks, although a recent study suggests that Kahilma-age rocks were deposited into two separate basins on either side of the Chulitna area, which formed a syndepositional structural barrier (Eastham and others, 2000). The Kahilma assemblage consists of a monotonous, highly deformed flysch succession of tine-grained lithic sandsione, argillite, highly siliceous argillite, and rare conglomerate and limestone of prehnite-pumpellyite metamorphic grade. This predominantly turbidite assemblage is several thousand meters thick. In the eastern map area, bedding and cleavage typically dip to the southeast. and fold vergence is predominantly to the northwest. In the norhwest. rypical bedding and cleavage dip is to the northwest with fold vergence predominantly to the southeast. Regionally the Kahiltma assemblage underlies a large area of southcentral Alaska, and locally includes large thrust sheets or nappes of Upper Triassic pillow basalt (Jones and others, 1980). Age of these rocks is based on Early Cretaceous fossils (belemnite guards and Inoceramus prisms) similar to those reponed by Jones and others (1980) recovered from the northwest map area (loc. 2-4 in Blodgen and Clautice. 2000) as well as regionaily reported Inoceramus, belemnites. and Buchia sublaevis of Cretaceous age, and radiolarians of Upper Jurassic age (Jones and others. 1980).

Below we subdivide the Kahilma assemblage into three mappable lithologic units: (1) argillite and sandstone, (2) sandstone and argillite and (3) conglomerate. 
KJas ARGILLITE AND SANDSTONE (Upper Jurassic to Lower Cretaceous) - Dark gray to very dark gray and black argillite (locally phyllitic) and dark gray sandstone. Rocks weather brown, orangc-brown, and reddishorange. Argillite is greater than 50 percent of this unit and locally sandstone may be as little as 10 percent of the unit. Cleavage is prominent in this unit and is commonly the dominant outcrop characteristic. Cleavage is commonly parallel to bedding, however, where it is not, the relationship gencrally indicates folding or overtuming with a northwest vergence. North of the East Fork Chulima River this unit is locally cross-cut by mafic and folsic dikes. White quartz veining, locally with sulfides, and locally as crystal-filled vugs and fracrures. is up $1030 \mathrm{~cm}$ thick and locally up to $2 \mathrm{~m}$ thick.

K.Jsa SANDSTONE AND ARGILLITE (Upper Jurassic to Lower Cretaceous) - Sandstone with much lesser argillite. Predominantly dark gray, poorly sorted, sub-angular, fine- 10 medium-grained lithic sandsıone, rhythmically layered with dark gray, locally carbonaceous argillite. Sandstone weathers dark gay, medium gray. and locally light gray or orange brown. Sandstone forms about 80 percent of this unit. Sandstone beds are laterally continuous, have sharp. non-erosive bases, are generally thin-bedded ivith lesser medium-bedded, and form rare amalgamated beds to $50 \mathrm{~cm}$ thick. Beds are massive or graded, with Bouma intervals $T_{a \rightarrow}, T_{b d s}$ and $\mathrm{T}_{\mathrm{de}}$ common. The depositional environment for this unit is a middle submarine fan (Muni and Ricci Lucchi, 1978) on the basis of sedimentary strucrures and bedding characteristics. Sandstone locally contains carbonate along with the ubiquitous clay matrix, and framework clast estimates are 70 percent quartz, 20 percent black argillite (low-grade metamorphic rock) including ripup clasts, 10 percent gray chen (with rare white ripolitic chert), and minor white mica. Cleavage is the dominant structural feature. Andalusite-sported homfels is locally found adjacent to plutons and dikes. In the headwaters of Antimony Creek it is cross-cut by a gabbro dike of probable Tertiary age. Includes rare conglomerate that is shown as map unit KJc where thicker than $\mathrm{l}$ in.

KJc CONGLOMERATE (Upper Jurassic to Lower Cretaceous) - Medium gray, poorly sorted, matrix-supported, polymictic pebble to cobble conglomerate. Matrix is fine- 10 medium-grained sandstone and constitutes about I5 to 20 percent of the rock. Clast estimates from the eastem part of the map area are 70 percent quartz. 20 percent black argillite, and 10 percent gray chen (with rare white tripolitic cher). Cobble to boulder conglomerate is noted to the northwest with sandstone argilfite, siltstone, and conglomerate clasts and minor coarse sand sequences with $a-b$ Bouma cycles.

\section{Older Assemblage}

The older assemblage forms the core of the map area and may lie in thrust contact above younger Kahiltna assemblage rocks. We believe it comprises a composite of Chulima, West Fork, and Broad Pass terranes (Jones and others, 1981) of earlier usage. This linkage is based on geophysical and lithochemical similiarities between Devonian volcanics (unit Dv) and associated serpentinite within the chassic Chulitna terrane and serpentinite and volcanics (within units uPzt, uPzst, and uPzs) of both West Fork and Broad Pass terranc. All units within this assemblage have been subjected to low-grade regional metamorphism; pre-Jurassic units have experienced grecnschist-facies metamorphism.

KJs CALCAREOUS SANDSTONE AND ARGILLITE. WITH COQUINOID LIMESTONE (Upper Jurassic to Lower Crelaceous) - Predominanily medium gray, poorly and very poorly soned, sub-angular with lesser sub-rounded. fine- to medium-grained, tan to light gray, orange-brown weathering, calcareous, lithic sandstone. The sandstone is interlayered with dark gray argillite, and rare coquina limestone to $2 \mathrm{~m}$ thick composed of comminuted Buchia sublaevis shells (Valanginian, Lower Cretaceous age, loc. 11 13, 38, 39, 93 in Blodgert and Clautice, 2000). Rare, thin-bedded, quanz grain-bearing carbonate (rubble only). Calcareous sandstone is the distinguishing lithology of this unit and composes less than 25 percent, whereas the unremarkable argillite constimtes more than 70 percent of this unit. Sandstone bedding is thin, parallel, laterally continuous, and conformable with coquina beds where the bounding clastic rocks are very-fine-grained red- 10 maroonweathering sandstone and siltstone. The distinctive coquinoid limestone weathers maroon to dark reddish-brown and is composed of broken shells. which locally range $104 \mathrm{~cm}$ in diameler. Contact relationships of this unit (whether faulted or depositional) are uncertain. It is most prevalent in the northwest map area, apparently overlying and folded with basaltic uff and limestone of unit TRIb, but is also present in the central map area. east of Copeland Creek, based on a Buchia occurrence (locality 93, Blodget and Clautice, 2000) within calcareous sandstone and thin-bedded limestone. This unit is isoclinally folded, and the resulting cleavage is the dominant fabric in the hinge regions and less dominant distal from the hinges. The closely spaced cleavage is especially prominent in the argillaceous lithologies where it locally forms pencil cleavage. 
Petrographic analyses indicate sandstone frame work grain averages are 60 percent cher, 10-15 percent polycrystalline quartz, 10-20 percent monocrystalline quartz, 10 percent 10 minor sedimentiry rock fragments. 5 percent to minor plagioclase, minor to trace volcanic rock fragments. and other irace minerals include white mica. hornblende. and glauconite. Aqua-blue chen clasts are rare but distinctive. Sandstone matrix is ironrich carbonate and calcite, with only a minor clay component. Matrix ranges from $5-15$ percent of the rock. with an average of less than 10 percent. Porosity in sandstone is very minor due 10 secondary carbonate cement. Sandsione petrography indicates a recycled orogenic provenance. Furthermore. the proverance is more characteristic of the collisional recycled orogenic provenance than the foreland uplift recycled orogenic provenance due 10: (1) more abundant plagioclase relative to lithic rock fragments. and (2) more polycrystalline quartz relarive to sedimentary rock fragments. The coquinoid limescone luyers within this map unit are rare but significant, and similar to coquinords of Valanginian age know'n in the Kandik basin of east-central Alaska and Yukon Territory. Addutionally, they are similar to coquinoids on the Alaska North Slope, which crop out along the foothills of the Brooks Range from the DeLong Mountains in the w'est to the Shaviovik front, east of the Dalton Highway. All of these deposits are within a siliciclastic strarigraphic package and represent shelfal deposition, in water depths of less than about $125 \mathrm{~m}$. All of these thin $(0.2-3.0 \mathrm{~m})$ carbonate horizons may represent a local sedintent flushing, wirnowing, and shell disaggregation (with no substantial transport) due to episodic high-energy storms, or this strattgraphy records destruclive reorganization of pelecypods which included some down-slope transport.

The relationship of this unit to Kahilma rocks of similar age is unctear. It is possible that it represents a nearshore facies of the deeper-water Kahilma assemblage.

Jac ARGILLITE, CHERTY ARGILLITE. AND MINOR CHERTY TUFF AND BASALTIC TUFF (Middle? to Upper furassic) - Mostly argillite exhibiting complex deformational fabrics and sub-greenschist metamorphic mineralogy. This unit is characterized by argillite and cherly argillite, with minor cherty ruff and basaltic tuff. Light gray to black rhythmically bedded chert predominates. In places this unit is highly sheared and phyllitic. Radiolanans from this unit are of Late Jurassic (Callovian to Tithonian) age (loc. 106, 107, 111, 112 in Blodgett and Clautice. 2000), while a single locality (locality 5) was recognized to be of undifferentiated Jurassic age.

Is CALCAREOUS SANDSTONE, SANDY LIMESTONE, AND ARGILLITE (Lower Jurassic) - Thin to medium, regularly bedded. brown weathering calcareous sandstone, sandy limestone and argillite. In places phosphatic and fossiliferous. Ammonites within this unit are or Sinemurian. Early Jurassic age (loc. 104, 105, 132, 137, 147, 152 in Blodgen and Clautice, 2000).

TRrb REDBED SANDSTONE AND CONGLOMERATE (Upper Triassic) - Red- to maroon-weathering, calcareous siliciclastic rocks (especially sandstone, siltstone, and conglomerate; sheet I, photo 5 ). The sandstones are commonly coarse-grained. hematitic. red-weathering, (but less commonly light-green weathering) with local calcareous cement. Red-weathering. matrix-supported, well-rounded pebble conglomerate with pebbles of white quart, basalt, and volcaniclastics is a distincrive lithology of this unit. No fossils were found within this unit for stratigraphic control, but these rocks appear to overlie the Upper Triassic limestone and basalt unit (TR/b). In rubble-crop exposures. with a decrease in hematite content and an increase in sandstone maturity, calcareous cement, and thin limestone layers. the lower portion of this unit appears to grade into Upper Triassic unit TRs. It is uncertain whethes this is rruly a gradational contacl. structural, or erosional contact.

TRs BROWN SANDSTONE AND ARGILLITE (Upper Triassic) - Thick-bedded, yellow-brown weathering sundstone and argillite with minor calcareous sandstone and sandy limestone. Abundantly fossiliferous horizons yield large (4 cm diameter) heterastridium (sheet 1, photo 6). snails. and bivalves of Late Triassic, Norian to Rhaetian age (loc. 150, 151 in Blodgett and Clautice, 2000). Contact relanons with adjacent units are not entirely certain. These rocks may represent a transitional, near-shore environment between the redbed sandstone and conglomerate (TRrb) above and the Upper Triassic limestone (UTRi) and limestone/basalt unit (TRIb) below.

TRIb BASALT, BASALTIC TUFF, AND LIMESTONE (Upper Triassic) - Predominantly massive (occasionally pillowed) basalt and basaltic ruff 50-100 m thick, interlaycred with fine-graned gray limestone (sheet I. photo 4). Near some contacis with basalt the limestone is coarsely recrystallized and sheared, other contacts display fossiliferous limestone immediately adjacent to basalt. Major to minor chlorite-albite-carbonatehematite alteration in the basalt is ubiquitous. The basalt is subalkaline (fjg. 8 a) and tholeiitic, characterized 


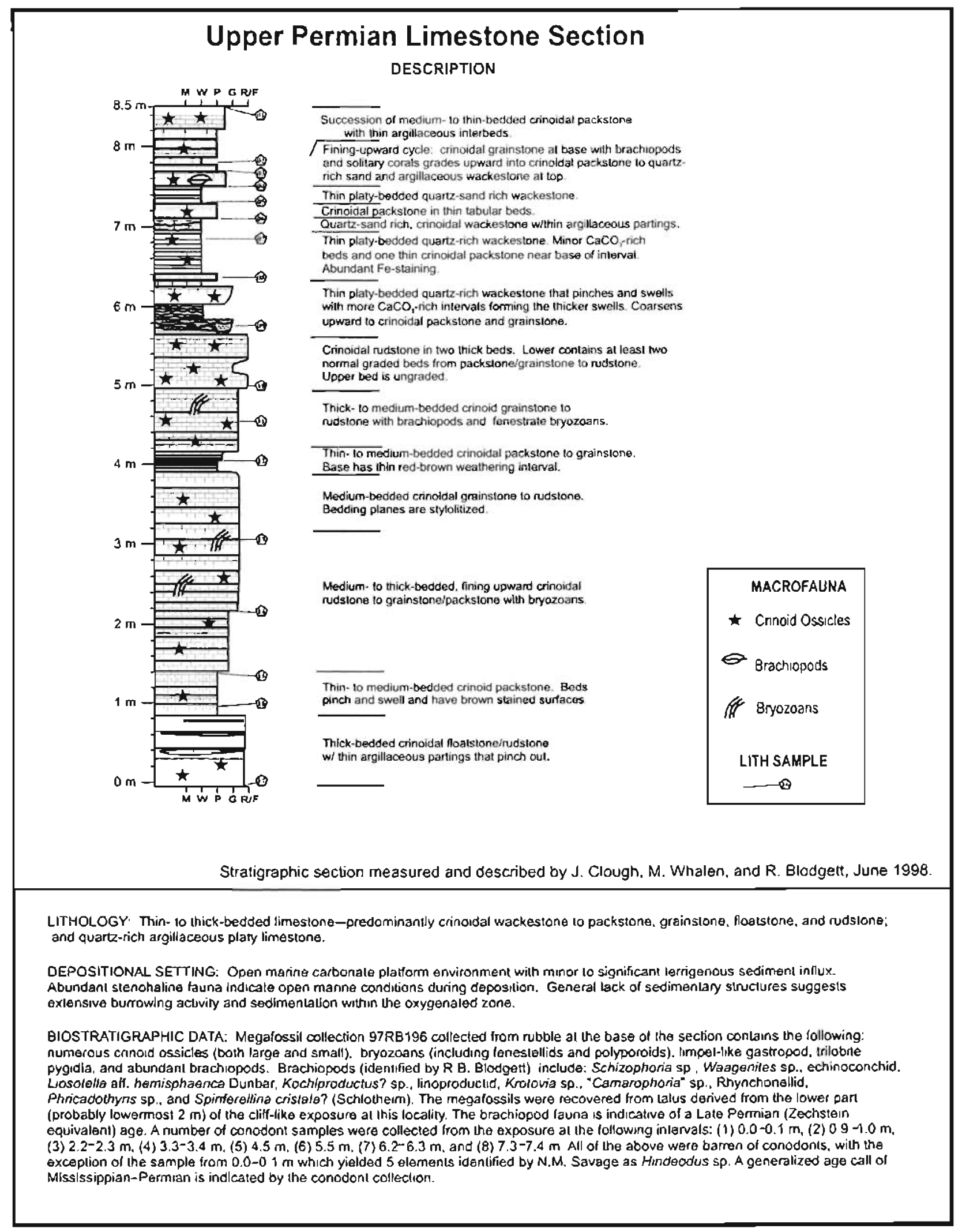

Figure 13. Upper Permian limestone sechion. 
by "within-plate" (Tace-element abundances (fig. 10), strongly magnetic, and dark-green weathering. Traceand major-element concentrations in the basaltic rocks (figs. 8a, 10a) are indistinguishable from those of the Late Triassic Nikolai greensione flood basalts (Davis and Plafker. 1985: Barker. 1994). The only other known Triassic basalts of significant thickness in the general area are in the 'Stikinia' terrane of the westem Canadian cordilicra: these have trace-element contents that contrast significantly (fig. 11) wills those of the Chulima area (Har, 1997). The limesiones contain colonial scleractinian corals, megalodontid bivalves, and the brachiopod Spondy/ospira lewerensis (Lees), and the age is Norian. Slightly younger. Norian to Rhaetian faunal assemblages are found in a light brown. calcareous sandstone within unit TRs, which lies unconformably(?) above TRIb. Below and intruded by basaltic dikes of this unit is unit Trus. of red-colored volcaniclastics and sandstones. Preliminary paleomagnetic investigations (Stone and others, 1999) indicure a paleolatitude of formalion for TRIb basalt at 5 degrees, consistent with the paleontologic record and the paleolatitude of the Nikolai flood basalt of southern Alaska. It is not known whether these rocks were normally or reversely magnetized, therefore it is not known whether this represents a paleolatitude north or south of the equator. Although faunal assemblages in TRIb limestones are slightly younger (Norian) than those associated with the limestones above the Nikolai basalı (Camian), the basalts are compositionally indistinguishable from Nikolai greenstone. Given the similar chemistry and that preliminary paleomagneric data suggest a similar latitude of formarion, we infer that basaltic rocks within TR lb constitute a slightly younger variant of the Nikolai units of southern Alaska. perhaps a moving hot spot that is part of the Wrangellia terrane, and consequently that itand by inference the associated rocks - is a part of the Wrangellia terrane as suggested by Jones and others (1980).

TRb BASALTIC DIKES AND SILLS (Upper Triassic) - Fine-grained. equigranular 10 porphyritic, strongly magnetic, mafic intrusive rocks, similar in appearance and indistinguishable in composition from the basalt of unit TRIb. Has been noted most commonly as dikes and sills. I-3 $\mathrm{m}$ wide, as well as plugs (?) or composite dikes in unir TRvs. ${ }^{\Delta 0} \mathrm{Ar} /{ }^{3 \omega} \mathrm{Ar}$ dating indicates a minimum age of $179 \mathrm{Ma}$ (table 2). These relations indicate that unit TRIb is younger than TRvs, contradicting the inferred stratigraphic relations of Jones and others (1980).

uTrl LIMESTONE (Upper Triassic) - Thirr- to thick-bedded limestone with subordinate shale and calcareous silistone, well bedded. Unut at least $300 \mathrm{~m}$ where welt exposed in the upper reaches of Long Creek. Carbonate lithologies include mudstone, wackestone, packstone and even rudstone (rare); locally with silty and argillaceous admixnures. A prominent interval composed of in-place colonial scleractinian thicket reefs crops out in the upper canyon of Long Creek. At this locality, the unit contains a rich and well-preserved Norian-age fauna of brachiopods, scleractinian corals, bivalves, and less common gastropods (loc. $51-53$ in Blodgen and Clautice, 2000. Stanley and Yarnell, in press). To the south, the unit can be traciod along strike for several miles within unit TRvs. Whether the contuct is structural or depositional is uncertain (plate 1, photo 9).

TRvs RED-COLOREO TUFF. ANDESITE, BASALT. GRAYWACKE. CONGLOMERATE (Middle? 10 Lower? Triassic, possibly older) - A predominanily volcanic and volcaniclastic unit of red-colored lithic cuff, lithic conglomerate, graywacke. Finely lammated tuffaceous siltstone and mudstone with minor basalt to dacite flows (sheet 1, photos 1, 7. and 9). Previously mapped as part of Jones and others" (1980) sedimentary redbeds. we delineate these primarily volcanic rocks (fig. 9) as a separate and older unit. Volcanic members are predominantly calc-alkalic andesite tuffs and iffr breccias, but compositions range fron calc-alkaline basalt to dacite. Generally non-magnetic due to oxidation of primary Fe-Ti oxides to hemalite: the combination of this oxidation and the common occurrence of calcite suggests conditions altemated between sub-serial and subaqueous deposition. Coarser volcaniclustic members are often calcareous, with a predominantly inedium- to very coarse-grained, poorly sorted matrix containing occasional feldspar, clinopyroxene. and homblende crystals. Lithic clases are subangular and consist of predominantly mafic volcanics frequently altered to chlorite, hematite, and calcite. Other lithic fragments include quartz, polycrystalline quarz, felsic volcanics, plutonic, and metamorphic rock.

Where present near Cretaceous intrusions, unit is homfelsed to a green, hard rock with remnant ruffaceous textures. Unconformably underlain by limestone containing fossils with ages ranging from Pennsylvanian(?) to Permian (loc. 24, 25 in Blodgen and Clautice, 2000). The unit is locally cut by dikes and sills of tholeiitic basalt conposition indistinguishable from unit TRlb. which furcher implses a pre-Upper Triassic age. The compositions (for example, fig. $1 \mathrm{lb}$ ) and lithologies (dominantly volcanic and volcaniclastic rocks) of the lower portion indicate a volcanic are affinity. This unit is correlative with the late Paleozoic and Early Triassic sedimentary and andesitic ruff unit of the Tangle subtcrane (Nokleberg and others, 1994). 
This unit directly overlies Permian limestone; where the limestone is absent it overlies Pennsylvanian-Permian mudstone and graywacke. The basal contact of the umit is a red cher-pebble conglomerate; the cher contains upper Devonian radiolaria that are apparently derived from unit Dc.

Consequently, we infer that in places the lower contacl of unit TRus represents a local unconfomity. The common red color of this unit is due 10 its andesitic-basaltic bulk composition and to syngenetic or diagenetic oxidation. Rarely, if ever, is this unil a hematitic sandstone. or a "redbed" in the commonly accepted use of the term. Total thickness is unknown, but at least $300 \mathrm{~m}$ thick and probably quite variable in thickness.

ITRI LIMESTONE (Lower Triassic) - Thin-bedded, light gray, light brown weathering mudstone and packstone. Recognızed within small, high-angle fault slivers in two localities in the nurtheastem map area. Both exposures are less than $4 \mathrm{~m}$ in strike length and $\mathrm{I}-2 \mathrm{~m}$ thick. In the eastemmost exposure, Nichols and Silberling (1979) recognized 1.3 identifiabie species of ammonite fossils in a single $10-\mathrm{cm}$-thick bed. The collection is significant because the closest rocks of similar age (Smithian) and equatorial paleolatitude ( 10 degrees) are found in northem Washington. At the time of our visit this exposure was in a cal trail near the Golden Zone mill and all fossils had been "mined." The second locality, about $2 \mathrm{~km}$ to the west, is exposed as orange-brown weathered, silicified packstone to wackestone with poorly-preserved fossil material in rubbly outcrop over a ferv square meters above a trail along an old flume (loc. 23 in Blodgett and Clautice, 2000). This unit is only exposed in high-angle fault slivers, for example, in fault contact with red-colored, coarse-grained volcaniclastics from unit TRvs.

PI LIMESTONE (Upper Permian) - Approximately $100 \mathrm{~m}$ thick succession of limestone subdivided into distinct lower and upper units (5ig. 13). Lower unit composed primarily of medium- 10 thick-bedded, light 10 medium gray weathering limestone. Carbonate lithology is predonzinantly encrinoidal packstone to grainstone. Upper unit composed of medium- to thick-bedded limestone, light gray to orange-yellow weathering and locally highly silicified. Lithologies include mudstone, packstone and grainstone, frequently with argillaceous partings. Horridonid brachiopods are common near top of upper member. The limestone contains abundant megafauna of "Arctic Permian" rype consisting of brachiopods, bryozoans, pelmatozoan debris. solitary rugose corals, ostracods, and trilobites of Late Permian age. Conformably and gradationally overlies a succession of Permian-age argillite and graywacke and is unconformably overlain by a thick "red bed" volcaniclastic scquence (unit TRvs).

PPs PERMIAN MUDSTONE AND GRAYWACKE (Pennsylvanion'? to Permian) - Unit is at least $200 \mathrm{~m}$ thick and composed of thinly bedded mudstone and graywacke (sheet I, photo 2). Lover part of unit dominated by gray-green graywacke turbidites that weather to yellow-brown, composed of lithic sandstones. 3-60 cm thick, interbedded with thin intervals of mudstone. Fossits not observed in the lower par of the unit. Thin-bedded, medium to dark gray and yellow-brown mudstone and siltstone predominate in the upper pan of this unit, with trace fossils of the ichnogenera Chondriles and Scalariluba, and relatively scarce small brachiopods, bivalves, and bryozoans near the top of the succession. Unit confomably and gradationally underlies Permian limestone unit (PI). Unit is well exposed along north-south-trending ridge in SE 1/4.NEl/4 Sec. 17, T20S, RII W, and along hillside both above and below ditch in NWI/4NE1/4 Sec. 4, T20S. RIIW.

uPzt TUFF (upper Paleozoic") - Described by Jones and others (1980) as unit JTRt, part of the West Fork tertane, this unit is characterized by predominantly dark gray-green, andesitic to rhyodacitic composition ash and crystal tuff, subordinate argillite, and cherty argillite, silistone, and grayivacke, and minor volcanic flows. The ish tufT is commonly "flinty" and layered in $5-30 \mathrm{~cm}$ varicolored beds of green, white, and tan, and is clearly welded in places (plate I, photo \$). Wispy layering is common within beds. The coarser crystal-lithic tuff occurs in thicker beds (greater than $1 \mathrm{~m}$ ), and hand specimens could be misidentified as sandstone. Basaltic10 andesitic-composition, angular, clast-supported tuff breccias occur in poorly-exposed lower-elevarion sites. Such rocks are compositionally indistinguishable from the nafic volcaniclastic rocks of unit Dv (figs. $8 \mathrm{a}, 10$ ). The interlayered sedimentary rocks are principally volcaniclastic sandstones, which appear to be reworked ruff from the same sequence. Compositional and textural similarities between this unit and unit Dv suggest that unit uPZt represents the upper (felsic tuff-dominant) portion of unit DV, partly removed during Early Carboniferous erosion prior to deposition of unit PPs. Consequently, we infer that the "West Fork terrane" of Jones and oihers (1980) is indistinguishable from the Paleozoic rocks in the Chulima region.

uPzst ARGILLITE AND TUFF (upper Paleozoic?) - With lesser siltstone and chert. Compositions and character of the varying rock types are the same as uPzt, although the relalive proportions are different. In this area, sedimentary rocks comprise about 85 percent of the unit, volcanic suffs about 15 percent. The contact with 
uPzt is Iransitional, and placed where sedimentary rocks are more abundant than tuffaceous rocks. This unit nua be equivalent to unt PPs. but definutive evidence is lacking.

uPzs CHERT, ARGILLITE, AND GRAYWACKE (upper Paleozoic?) - Part of Jones and others (1980) Broad Pilss terrane and Csejety and others (1992) Crelaccous melange. This unit is poorly exposed, and includes a variery of lithologies found in steeply incised dranages where continuous traverses are not feasible. Lithologies encountered include bedded chern (upper Paleozoic based on radiolarıans. Jones and others, 1980) and carbonaceous, fissile black argillite with yellow- and orange-wcathering salıs, basalı, cherty tuff. green volcaniclastic rock, siltstone, graywacke (wilh black and occasionally red chert grains) and clast-suppored. white quarz-pebble, black argillite (occasionally red argillite) conglomerate. Limestone (unit Dl) crops out in Copeland Creek and Long Creek canyons and contains fossils thought to be identical to a Givetian (late Middle Devonian) fauna from Healy B-4 Quadrangle described by Blodger (1977). A narrow, northeasttrending aeromagnetic high raverses the unit and in three locitions coincides with outcrops of very magnetic serpentinite as found to the northwest associated with unit Dv. Based on similar lithologics. upper Paleozoic rossils, and the serpentinite trend, this "unil" may in part, represent a structural reperition of the upper Paleozoic rocks found to the norhwest.

Dv ANDESITIC: TUFF AND FLOWS (Upper Devonian) - Predominantly green-wedthenng, pyroxene andesite tuff and flows, but compositions range from island-are tholeituc basalt (locally pillowed) to dacitic tuff (fig. 8a). Previously mapped as "Tertiary gabbro breccia" in the Golden Zone mine area (Hawley and Clark. 1974) and as part of a Devonian opholice (Jones and others, 1980). The lower contact is incerlayered with Upper Devonian (Famennian) radiolarian chent. The upper contacl is dilficult 10 discern, appears to be somewhat gradational. and may represent either an erosional unconformity or interfingering wsth overlying sedimentary rocks of unit PPs. Lower greensch ist metamorphism is ubiquitous, as chlorite-albite-carbonateepidoce alteration of primary mafic and feldspar minerals. Immobile clement compositions (fig. 10) indicate this unit formed as an intra-oceanic island arc. Compositional similaritics to spatially associated gabbro blocks with serpentinite suggest that the units Dv. Dc, and sp represent different structural levels within an island arc.

De RED AND BROWN CHERT (Upper Devonian) - Radiolarian chen, massive 10 well layered, predominantly red and brown, but also green and black. Locally manganiferous, with up to 0.5 percent $\mathrm{MnO}$, and ferriginous. Radiolaria indicate a Late Devonian (Famennian) age. Found bedded in the lower portions of the Devonian tuff (unit Dv), but rarely of areal extent large enough to be mapped: also as large pods and blocks in fault zones, most notably in the drainage in southcentral portion of Sec. 16, T20S, RIIW, where it occurs within serpentinite. Red cher clasts from this unit are found within conglomerate in unit TRvs.

DI LIMESTONE (Early? to Middle Devonian) - Medium- 10 thick-bedded, medium to dark gray lime mudstone to wackestone: locally fossiliferous with bolh rugose and tabulate corals, and brachiopods. Megafossils from the field area (loc. I|4-1|6, Blodgen and Clautice. 2000). as well as equivalent exposures in the Reindeer Hills. Healy C-4 Quadrangle (Blodgent, 1977) indicate a Middle Devonian or slightly older age, although one locality in she field area yielded conodones idenufied as being of Late Silurian (latest Pridolian) or Early Devonian (Gedinnian, or Lochkovian) age (Jones ind others. 1980).

\section{ROCKS OF UNKNOWN AGE}

SERPENTINITE GABBRO AND SILICA-CARBONATE ROCKS - Mixed unit varying from intensely serpentinized, chromite-bearing dunite 10 altered gabbro (sheet $I$, photo 7). Serpentinite is commonly altered to silica-carbonate rock and is ocherwise strongly magneric. Gabbro is commonly layered. and varies from fine- to coarse-grained and from leucocratic to melanocratic altered clinopyroxene-plagioclase rock. Plagioclase is ubiquitously altered to clinozoisite-albite-sericite and pyroxene to chlorite-carbonate-epidote. Majorand trace-element similarities of the gabbro to basaltic members of the Devonian(?) volcaniclastic unit (Dv) suggest that the gabbros were feeders for the Devonian volcanics. Generally occurs as tectonic lenses occupying the hinge zones of antiforms within Devonian (?) volcanic unit (Dv) and along faulis separating unit Dv from unit TRus. Devonian age suggested due to common spatial proximity with Devonian chert unit, but age is not well constrained.

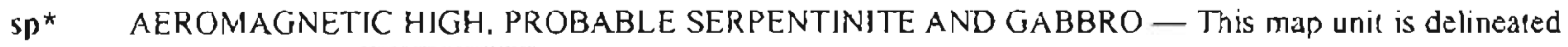
by a narrow, strong magnetic signature that trends northeast through Broad Pass (sheet 1 . aeromagnetic map). Serpentinite was found in three locations in this area of linle bedrock exposure and at one locality near basalt with major- and trace-etement sinilarities to unit Dv. This unit is believed to be very similar to unit sp above. 


\section{INTRUSIVE ROCKS}

$\mathrm{Tg}_{\mathrm{g}}$ BIOTITE GRANITE (Eocene) - Textures range from fine-grained porphyritic (d)kes) to coarse-grained, sub-equigranular. Normative compositions indicate most rocks are classified as alkali feldspar granite and lesser syeno-granite (fig. 12a). Locally altered to tourmaline-zinnwaldite \pm biolite granite. Generally ilmenite series. lacking primary magnetite and sphene. Minor plases include topaz, zircon. apatite. and fluorite. ${ }^{10} \mathrm{Ar} /$ ${ }^{39}$ Ar dating of these rocks indicates a range in age from about $46 \mathrm{Ma}$ 10 $55 \mathrm{Ma}$ witls most betwcen about 50 and $55 \mathrm{Ma}$ (table 1). Trace-element data (fig. 12b) indicate the rocks are highly fractionated members of collision- or extension-related felsic magmas. Narrow basaltic or lamipropheric dikes (Tb) commoniy inirude these bodies.

Tb BASALTIC-COMPOSITION DIKES (Eocene) - Nartow ( 0.3 - $2 \mathrm{~m}$ wide), fine-grained, dark-colored, mafic dikes that cut Late Cretaceous granites. Most readily distinguished in the field by rare clinopyroxene phenocrysts, up $102 \mathrm{~cm}$ in size, and by occurrence with Tertiary granite. Major and ninor element compositions indicate these are exclusively of basalt composition, and some are alkali bisalt (figs. 8b. 12). These rocks typically possess magnetic susceptibilitics internediate berween thosc of units Trb and $\mathrm{Km}$. Immobile element conpositions indicate an extensional-related setring (fig. I $0 \mathrm{~b}$ ); most likely they represemt the mafic member of an early Tertiary bimodal magmatic sulte. ${ }^{40} \mathrm{Ar} /{ }^{30} \mathrm{Ar}$ dating of one dike indicates an age of about 52 Ma (table I).

Kg LATE CRETACEOUS (HORNBLENDE) BIOTITE GRANITE - Monzo- and syeno-granite composition rocks (fig. 12a) with ${ }^{40} \mathrm{Ar} / 39 \mathrm{Ar}$ minimum ages (table 2) of aboul 61.4 to $71 \mathrm{Ma}$. On the west side of the Parks Highway these are seen as dikes and small stocks with granite porphyry textures; on the east side as large bodies of sub-equigranular granite with grain sizes of $2 \mathrm{~mm} 102 \mathrm{~cm}$. These racks appear to be compositionally and mineralogically transitional to $\mathrm{Km}$, with no sharp compositional break berween the two (fig. 12a). Modal abundances are typically $20-30$ percent quartz. $30-40$ percent plagioclase $\left(A n_{5-15}\right), 30-40$ percent $K$-feldspar (chiefly orthoclase) and 5-10 percent biotite. Trace amounts of hornblende, zircon, apatite, and ilmenite are also present. Rocks of this unit commonly display moderate to extensive hydrothermal alteration: biotite to muscovite + chlorite + rutile and plagioclase to calcite + fine-grained white mica.

Unit $\mathrm{Kg}$ is distinguished with difficulty from $\mathrm{Tg}$ in the field, especially in the central part of the map area, where both occur as rhyolite porphyry dikes. $\mathrm{Kg}$, however, characteristically lacks loumaline, fluorite, and coarse-grained muscovite. In the southeast part of the map area. $\mathrm{Kg}$ typically occurs as texturally and mineralogically monolonous biotite granite, lacking appreciable chıll. or pegmatite- or aplite-lextured zones. Compositionally, rocks of unit $\mathrm{Kg}$ generally contain lower $\mathrm{Rb}$ and $\mathrm{Nb}+\mathrm{Y}$ (fig. 12b) and higher normative anorthite (fig. 12a) than $\mathrm{Tg}$. Trace-element contents suggest that unit $\mathrm{Kg}$. like $\mathrm{Km}$. is of an arc-related origin (fig. 12b).

$\mathrm{Km}$ INTERMEDIATE COMPOSITION PLUTONIC ROCKS (LATE CRETACEOUS) - Bodies of Km range in size from small stocks to narrow dikes. typically oriented northeast-southwest. Rack textures vary considerably. from fine-grained porphyritic to medium-grained, sub-equigranular. The dominant mafic mineral is homblende; biotite is common in more felsic, and climopyroxene in more mafic, varieties. Minor 10 major chlorite-carbonate-sericite-albite-epidote-pyrite (propylitic) alteration is common. Generally ilmenite series, that is, lacking primary magnetite and sphene. Minor phases include zircon, allanite, and apatite.

Compositions are dominantly quartz monzodiorite, but quanz diorite, quartz monzonite, and granodiorite are also present (fig. 12a). Despite their generally quarz-poor character, trace-element contents indicate a volcanic arc-related origin (fig. 12b) ${ }^{40} \mathrm{Ar} /{ }^{39} \mathrm{Ar}$ dating of these rocks and their homfels zones (table 2) indicates a spread of ages from about $67 \mathrm{Ma}$ to $71 \mathrm{Ma}$; some of the younger ages have been thermally reset and the true age spread is likely narrower. Most $\mathrm{Km}$ dikes are easily recognized in the field by their distinctive homblende phenocrysts. Fine-grained and mafic varielies of $\mathrm{KM}$ are distinguished from mafic dikes of units Trb and Tb by distinctive immobile element contents (fig. 8b) and their lower magnetic susceptibilities. Similarities in age (about $70 \mathrm{Ma}$ ) as well as major and minor element compositions (Szumigala, 1993; McCoy and others, 1997) suggest that this igneous suite represents the same Late Cretaceous. intermediate composition magmatic event as the gold-related Kuskokwim Mountains magmatic belt of southwestern Alaska. 


\section{ACKNOWLEDGMENTS}

C.C. Hawley shared his expentise on the geology, mineral deposits. and mining history of the Chulitna district in adduion 10 providing accommodations. Several University of Alaska Fairbanks students contributed to the project: Sara Haug assisied in the field, Adam Low provided a report on existing literature and geophysical interpretations, Ben Gage and Paul Chu compiled geochemical data. Paleontologic work was under the direction of Rober Blodgen with assiscance provided by M.Z. Won and Paula Noble (radiolarians): Chris McRobens. Michael Sandy and George Stanley (Mesozoic megafossijs); and Norman Savage (conodonts). Michael Whalen assisted with measuring the Permian limestone section. David Stone, with sudents Howard Scher and Chad Schopp, conducted paleomagnetic studies. Paul Layer. Deitre Hansen. Kaitlin Hansen, and Jeff Drake with the University of A laska Geochronology Lab. performed ${ }^{40} \mathrm{Ar} /{ }^{39} \mathrm{Ar}$ geochronology. Paul Layer also provided considerable advice in interpretation of the Argon spectra. Mike Messing shared his mapping, photographs, and rock samples from the Honolulu Creek area. While all authors were involved in many aspects of the mapping project, special contributions were provided by Rainer Newberry (economic, structural and geologic interpretalions, trace-element diagrams), Tom Bundezen (Kahilna rocks in the norihivest map area), Ellen Harris (units Jac. uPzt, uPzst). Shirley Liss (units Jac, uPzi, Dv), Mari Miller (units TRvs, uPzr, uPzst), Rocky Reifenstuhl (units TRvs, KJs and Kahilma rocks in the eastern map area). Jim Clough (units PI and Tcs), ano DeAnne Pinney (unit Ts). Review of this report was provided by Laurel Bums, Jeanine Schmidt, and Chuck Hawley and editing by Paula Davis.

Partial funding for this project was provided through U.S. Geological Survey STATEMAP Cooperative Agreement 98HQAC2083.

\section{REFERENCES CITED}

Alaska Division of Geological \& Gcophysical Surveys, Dighen and WGM. 1997a, $7200 \mathrm{~Hz}$ resistiviry contours of the Chulitna mining dismict, Alaska: State of Alaska. Division of Geological \& Geophysical Surveys Report of Investigations 97-4, I sheet. full color. scale 1:63.360.

$-19976,900 \mathrm{~Hz}$ resistivity contours of the Chulima mining districl, Alaska: State of Alaska, Division of Geological \& Geophysical Surveys Report of Investigations 97-3. I sheet, full color, scale 1:63.360.

-1997c, Total field magnetics and electromagnelic anomalies of the Chulima mining district, Alaska: State of Alaska, Division of Geological \& Geophysical Surveys Repor of Invesigations $97-1$. I sheeL 3 colors, scule 1:63.360.
Alaska Division of Geological \& Geophysical Surveys, Dighem and WGM, 1997d. Total field magnetics of the Chulitna mining districi. Alaska: State of Alaska, Division of Geological \& Geophysical Surveys Repon of Investugations 97-2, 1 sheet, full color. scale 1:63.360.

Alhey, J.E.. 1999. Characterization of the DAT Zone. Eastern A laska Range, Alaska: University of Alaska Fairbanks, unpublished M.S. Thesis. $137 \mathrm{p}$.

Balen. M.D., 1990. Geochemical sampling results from Bureau of Mincs Investigations in the Valdez Creek mining district. Alaska: U.S. Bureau of Mines OpenFile Report 34-90, $218 \mathrm{p}$.

Barker, Fred, Aleinikoff, J.N. Box, S.E., Evans, B.W., Gehrels. GE., Hill. M.D., Jrving, A.J., Kelley, J.S., Lceman. W.P., Lull, J.S., Nokleberg. W.J., Pallister. I.S., Parrick, B.E., Plafker, George, and Rubin, C.M., 1994, Some accreted volcanic rocks of Alaska and their elemental abundances, in Plafker, George, and Berg, H.C., eds., The geology of Alaska, the geology of North America: Boulder, Colorado, Geological Sociery of America, v. G-1, p. 555-587.

Barker, Fred, Sutherland Brown. A., Budahn, J.R., and Plafker, George, 1989. Back-arc with frontal-arc component of the Triassic Karmutsen Basalt, British Columbia, Canada: Chemical Geology, v. 75. p. 81102.

Beard. J.S., and Barker. Fred, 1989. Petrology and tectonic significance of gabbros. tonalites, shoshonites, and anorthosites in a Lace Paleozoic arc-rool complex in the Wrangellia terrane. southern Alaska: Journal of Geology, v. 97, p. 667-683.

Bhatia, M.R., 1983, Plate tectonics and geochemical composition of sandstones: Journal of Geology, v. 91. p. $611-627$

Blodgell, R.B.. 1977. A Givetian (late Middle Devonian) fauna from Healy 8-4 Quadrangle, central Alaska Range, Alaská, in Shor Notes on Alaskan Geology1977: Alaska Division of Geological \& Geophysical Surveys, Geologic Report 55, p. 1-2.

Blodgen. R.B., and Clautice, K.H., 2000, Fossil locality inap for the Healy A-6 Quadrangle, southcentral Alaska: Alaska Division of Geological \& Geophysical Surveys Report of Investigations 2000-5, 42 p.. 1 sheet, scale 1:63,360.

-Brooks. A.H., and Prindle. L.M., 1911, The Mount McKinley region. Alaska; descriptions of the igneous rocks and of the Bonnifield and Kantishna districts: U.S. Geological Survey Professional Paper 70, p. 136154, scale 1:625,000.

Bums. L.E., 1997. Portfolio of aeromagnetic and resistivity maps of the Chulitna mining district: Alaska Division of Geological \& Geophysical Surveys Public-Data File Repor 97-7. 13 p.

Capps. S.R. 19/9, Mineral resources of the upper Chulima region: U.S. Geological Survey Bullerin 692D. p. 207-232. 
Capps, S.R.. 1940, Geology of the Alaska Ruilroad region: U.S. Geological Survey Bulletin 907, 201 p., scale $\mathrm{I}: 250,000$.

Clark, A.L., Clark, S.H.B, and Hawley, C.C.. 1972, Significance of upper Paleozoic oceanic crust in the upper Chulima districh west-central Alaska Range: U.S. Geological Survey Professional Paper 800-C. p. C95-C101.

Clautice, K.H., Newberty, R.J., Blodgett, R. B., Bunduen. T.K., Gage, B.G, Hamis, E.E. Liss, S A., Miller, M.L., Pinney, D.S., Reifenstuhl, R.R., Clough, J.G., Stone. D.B., and Whalen, M.T.. I999a, Preliminary geologic map of the Healy A-6 Quadrangle. soulhcentral Alaska: Alaska Division of Geological \& Geophysical Surveys Public-Data File 99-24a, 28 p., 1 sheet, scale $1: 63,360$.

Clautice, K.H., Newberry, R.J.. Blodgett. R.B., Bundıen. T.K., Gage, B.G, Harris, E.E., Liss, S.A., Miller, M.L., Reifenstuhl, R.R., Clough, Pinney, D.S., J.G. Stone. D.B., and Whalen, M.T., 1999b, Preliminary interpretive bedrock geologic map of the Healy A-G Quadrangle, southcentral Alaska: Alaska Division of Geological \& Geophysical Surveys Public-Data File 99-24b, 26 p., l sheet, scale I:63,360.

Csejtey. Béla, Jr., Cox, D.P., Evarts, R.C. Stricker, GD., and Foster, H.L., 1982. The Cenozoic Denali fault system and the Cretaceous accretionary development of southern Alaska: Joumal of Geophysical Research. v. 87, no. B5, p 3,741-3,754.

Csejtey, Béla, Jr., Mullen, M.W., Cox, D.P., and Stricker, G.D., 1992, Geology and geochronology of the Healy Quadrangle, south-central Alaska: U.S. Geological Survey Map I-1961, 63 p., scale I:250,000, 2 sheets.

Csejtey, Béla, Jr., Nelson, W.H., Jones, D.L., Silberling, N.J., Dean, R.M., Morris. M.S., Lanphere. M.A., Smith, J.G, and Silberman, M.L., 1978, Reconnaissance geologic map and geochronology, Talkeetna Mountains quadrangle, norhern part of Anchorage quadrangle, and southwest comer of Healy quadrangle, Alaska: U.S. Geological Survey Open-File Report 78-558A, 62 p., scale 1:250,000.

Davis, Alice, and Plafker, George, 1985, Comparative geochemistry and petrology of Triassic basaltic rocks from the Taku Terrrane on the Chilkat Peninsula and Wrangellia: Canadian Joumal of Earth Sciences, v. 22, p. I83-194.

Eastham, K.R, Ridgway, K.D., and Lesh, M.E., 2000, Structural configuration and stratigraphy of the Kahilma basin(s): A detailed look at the 'Black Crap' of central Alaska (abstracl), in Summit 2000, Geological Society of America Annual Meeting, Reno, Nevada, Nov 9-18, 2000, Abstracts with Programs, v. 32 , no. 7, p. A 171 .

Fryda, J., and Blodgetl, R.B., in press (200l), Chulimacula, a new paleobiogeographically distinc- live gastropod genus from Upper Triassic strata in accreted terranes of southem A laska: Journal of Czech Geological Society, v. 46, (nos. 3-4).

Gage, B.G. Chu, P.S., Liss, S.A., and Claulice, K.H., 1998. Preliminary geochenical and major oxide data: Chulitna project. Healy A-6 Quadrangle and nearby areas (1997 \& 1998 data): Alaska Division of Geological \& Geophysical Surveys Public-Data File 98-36a, 48 p., 2 sheets, scale I:63.360. I disk.

Hart, C.J.R., 1997, A transecl across norhern Stikinia: geology of the northern Whitehorse map area, southern Yukon Territory: Yukon. Exploration and Geological Services Division, Indian and Northern AlTairs Canada. Bulletin 8, $112 \mathrm{p}$.

Hawley, C.C., and Clark, Allen L., 1973, Geology and mineral deposits of the Chulitna-Yentna Mineral Belt. Alaska: U.S. Geological Survey Professional Paper 758-A. D. Al-A10, 2 sheets, scales 1:250,000, 1:500,000.

-1974, Geology and mineral deposits of the Upper Chulitna district, A laska: U.S. Geological Survey Professional Paper 758-B, p. BI-B47, scales 1:48,000, $1: 24,000,1: 12.000$.

Hawley, C.C. Clark. A.L., and Benfer. J.A., 1968, Geology of the Golden Zone mine area, Alaska: U.S. Geological Survey Open-File Repor 68-122 (305), 16 p., $1: 2,400$ scale.

Hawley, C.C.. Clark, A.L., Hendrick, M.A., Clark, S.H.B., 1969, Results of gcological and geochemical investigations in an area northwesi of the Chulima River. cenıral Alaska Range: U.S. Geological Survey Circular $617,19 \mathrm{p}$.

Hopkins, D.M. 1951, Lignite deposits near Broad Pass station, Alaska, in Bames, F.F., Walurhaftig, Clyde, Hickcox, C.A., Freedman, Jacob, and Hopkins, D.M., eds. Coal investigations in south-central Alaska, 1944 46: U.S. Geological Survey Bulletin 963-E, p. 187-191.

Jones, D.L., Silberling, N.J., Csejtey, Bẻla, Jr., Nelson, W.H., and Blome. C.D., 1980, Age and structural significance of ophiolite and adjoining rocks in the upper Chulitna district, south-central A laska: U.S. Geological Survey Professional Paper 1121-A, p. AI-A21, 2 plates in text, I sheet, scale $1: 63,360$.

Jones, D.L., Silberling, N.J., Berg, H.C., and Plafker, George. 1981, Map showing tectonostratigraphic terranes of Alaska, columnar sections and summary description of terranes: U.S. Geological Survey OpenFile Repor 81-792, 20 p.. 2 sheets. scale l:2,500,000.

Kurtak, J.M., Southworth, D.D., Balen, M.D., and Claurice, K.H., 1992, Mineral investigations in the Valdez Creek mining district, south-central Alaska: U.S. Bureall of Mines OFR 1-92,658 p.

Layer, P.W., Hall, C.M., and York, Derek, 1987. The derivation of ${ }^{4 \pi} \mathrm{Ar} /{ }^{39} \mathrm{Ar}$ age spectra of single grains of 
homblende and biotite by laser step-heating: Geophysical Research Letters, v. I4. p. 757-760.

Lighı, T.D. Tripp. R.B.. and King. H.D., 1990, Interpretation of reconnaissance geochemical data from the Healy quadrangle. Alaska: U.S. Geological Survey Bullewn 1894, 36 p.

Mackevell, E.M., Jr., Cox, D.P.. Potler, R.W., and Silberman. M.L.. 1997. Kennecotr-type deposits in the Wrangell Mountains, Alaska: High-grade copper ores near a basalt-limestone contacl, in Goldfarb. R.J., and Miller, L.D., eds.. Mineral Dcposiss of Alaska: Economic Geology Monograph 9. p. 66-89.

Mason, Brian, 1966, Principles of Geochemisıry (3rd edition): New York, John Wiley \& Sons, $329 \mathrm{p}$

McCoy, Dan, Newberry, R.J.. Layer, P.W'. DiMarchi, I.J., Bakke, A.A., Masterman, J.S., and Minehane. D.L., 1997. Plutonic-related gold deposits of Interior Alaska, in Goldfarb, R. J., and Miller, L.D., eds., Mineral Deposits of Alaska: Economic Geology Monograph 9, p. $191-241$.

Meinert, L.D., 1992. Skams and skam deposits: Geoscience Canada, v. 19, p. 145-162.

Merill, R.D., and Hawley. C.C., 1986, Map of Alaska's coal resources: A laska Division of Geologıcal \& Geophysical Surveys Special Repor 37. I sheet, scale $\mathrm{I}: 2,500,000$.

Molfit, F.H., 1915, The Broad Pass region. Alaska, with seclions on Quatemary deposits, igneous rocks, and glaciation by J.E. Pogue: U.S. Geological Survey Bulletin 608, 80 p.. scale $1: 250,000$.

Montayne, Simone. and Whalen. M.T., in press, Permian cool-water limestones from the Chulima Terrane, southcentral Alaska, in Clautice, K.H., and Davis, P.K.. Alaska Division of Geological \& Geophysical Surveys. Short Noles on Alaska Geology 2001.

Mulligan, J.J., Warileld, R.S., and Wells. R.R., 1967, Sampling a gold-copper deposit, Golden Zone mine. south-central Alaska: U.S. Bureau of Mines open file report 9-67, $59 \mathrm{p}$.

Mutti. E. and Ricci Lucchi. F., 1978. Turbidites of the northem Appenmines: Introduction to facies analysis: International Geology Review, v. 20, no. 2. p. 125 166.

Newberry, R.J., 1995, An update on skam deposits of Aluska: Alaska Division of Geological \& Geophysical Surveys, Public-daca File 95-20,87 p.

Newberry, R.J. and Solie, D.N., 1995, Data for plutonic rocks and associated gold deposits in Interior Alaska: Alaska Division of Geological \& Geophysical Surveys Public-dasa File 95-25.62 p.

Newberty, R.J. Allegro, GL., Curter, S.E., Hagen-Levelle, J.H., Adams, D.D.. Nicholson, L.C., Weglarz, T.B., Bakke, A.A., Clautice, K.H., Coulter. G.A.. Ford. M.J., Myers, GL., and Szumigala, D.J., 1997, Skam De- posits of Alaska, in Goldfarb, R.I., and Miller, L.D.. eds., Mineral Deposils of A laska: Economic Geology Monograph 9. p. 355-395.

Nichols, K.M., and Silberling. N.J., 1979. Early Triassic (Smithian) ammonites of paleoequatorial affinicy from the Chulima 1errane, south-central Alaska: U.S. Geological Survey Professional Paper II2I-B, 5 p.

Nokleberg, W.J.. Planker, George, and Wilson. F.H., 1994, Geology of south-central Alaska, in Plafker, George, and Berg. H.C., eds. The Geology or North America, The Geology of Alaska: Geological Society of America. v. G-1. p. 311-366.

Parker. Tracey V.L.. 1991. Mineralization in the Coal Creek in prospect, south-central Alaska: U.S. Bureau of Mines ficld reporn, unpublished, 2 cross secrions and $36 \mathrm{p}$.

Pearce, J.A., and Cann. J.R.. 1973, Tectonic serring of basic volcanic rocks determined using trace element analyses: Earth and Planetary Science Letters, v. 19, p. 290-300.

Pearce, J.A. . Harris, N.B.W., and Tinúle, A.G., 1984, Trace element discrimination diagrams for the tectonic interpretation of granitic rocks: Joumal of Petrology, $v$. 25, p. 956-983.

Pinney. D.S., 1999a, Reconnaissance engineering geologic map of the Hesly A-6 Quadrangle, southcentral Alaska: Alaska Division of Geological \& Geophysical Surveys Public-Data File 99-24d, 4 p., I sheel, scale I:63,360.

1999b, Reconnaissance surficial geologic map of the Hcaly A-6 Quadrangle, southcentral Alaska: Alaska Division of Geological \& Geophysical Surveys Public-Data File 99-24c, 3 p., I sheet, scale 1:63:360.

Platker, George, and Berg, H.C.. editors, 1994, The Geology of Alaska, Decade of Nonh American Geology, Volume G-1. Gcological Society of America, 1055 p.

Reed, B.L., and Nelson, S.W., 1980, Geologic map of the Talkeetna quadrangle, Alaska: U.S. Geological Survey Miscallaneous Investigations Series Map [-1174. scale $1: 250,000$.

Reger. R.D., and Pinney, D.S., 1996. Late Wisconsin glaciation of the Cook Inlet region with emphasis on Kenai Lowland and implications for early peopling. in Davis, N.Y., and Davis, W.E., eds., Adventures through time: Readings in the anthropology of Cook Inlet. Alaska: Anchorage, Cook Inlet Historical Sociely, p. 15-35.

Richards, M.A., Jones, D.L., Duncan, R.A., and DePaolo, D.J. 1991. A mantle plume initiation model for the Wrangellia flood basalt and other oceanic plateaus: Science, v. 254. p.263-267.

Ross, C.P., 1933, Mineral deposits near the West Fork of the Chulina River, Alaska: U.S. Geological Survey 
Bulletin 849-E, p. 289-333. I sheet. scale 1:125.000. Samson. S.D., and Alexander. E.C.. 1987. Calibration of the interlaboratory "A $r_{-}-4$ Ar dating standard. MMhlyI: Chemical Geology, v. 66, p. 27-34.

Sianley, G.D. and Yamell, J.M., in press, New paleontological investigations of Triassic carbonate rocks in the upper Chulitna distsicr (Chulitna terrane), southcentral Alaska, in Clautice. K.H., and Divis. P.K., eds., Short Notes on Alaska Geology 2001: Alaska Division of Geological \& Geophysical Surveys.

Steiger, R.H. and Jaeger, E.. 1977. Subcommission on geochronology: Convention on the use of decay constants in geo and cosmochronology: Earth and Planetary Science Letters, v. 36. p. 359-362.

Stone, D.B.. Scher, Howard, and Schopp, Chad, 1999. Chulitna-area paleomagnetic studies: A laska Division of Geological \& Geophysical Surveys Raw-Data File 1999-2, 3 p.

Streckeisen, A.L., and LeMaite, R.W., 1979. A chemical approximation to the modal QAPF classification of the igneous rocks: Neues Jahrbuch fur Mineralogie Abhandlungen, v. 136, p. 169-206.

Swainbank. R.C., Smsth, T.E., and Tumer, D.L.. 1977 , Geology and K-Ar age of mineralized intrusive rocks from the Chulitma mining district, central Alaska, in Short notes on Alaskan Geology-1977: Alaska Division of Geological \& Geophysical Surveys. Geologic Report 55, p. 23-28.

Szumigala, D.J., 1993. Gold mineralization related to Cretaceous-Teniary magmatism in the Kuskokwim Mountains of west-central and southwestern Alaska: Los Angeles, California, University of California, unpublished Ph.D. disseration, 301 p.
Ten Brink. N.W.. 1983, Glacialion of the norhern Alaska Range. in Thorson. R.M.. and Hamilton, T.D.. eds. Glaciation in Alaska: Extended abstracts from a workshop: A laska Qualemary Cenier. University of Alaska Museum Occasional Paper No. 2. p. 82-91.

Walorhaftig, Clyde. 1944, Coal deposits of the Costello Creek basin, Alaska: U.S. Geological Survey OpenFile Report 8, 7 p. 6 sheets.

Wahrbaftig. Clyde, 1958, Quatemary geology of the Nenana River valley and adjacent parts of the Alaska Range: U.S. Geological Survey Professional Paper 293, p. $1-68$.

Wahriaftig, Clyde, and Black. R.F. 1958, Engineering geology along part of the Alaska Railroad: U.S. Geological Survey Professional Paper 293-B, p. 79-118. 6 sheets. scale 1:63,360.

Wamer, J.D., and Dahlin, D., 1989. Tin occurrences associated with the Ohio Creek pluton, Chulima region, south-central Alaska: U.S. Bureau of Mines OpenFile Repon 5-89. 29 p.

Winchester, J.A. and Floyd. P.A.. 1977. Geochemical discrimination of different magma series and their differentiation products using immobile elements: Chemical Geology, vol. 20, p. 325-343.

Won, M.Z., Blodgett, R.B., Clautice, K.H., and Newberry, R.J., 2000, Late Devonian (late Famennian) radiolarians from the Chulitna terrane, southcentral Alaska, in Pinney. D.S., and Davis. P.K.. eds.. Shor Notes on Alaska Geology 1999: Alaska Division of Geological \& Geophysical Surveys Professional Report 119, p. 145-!52. 


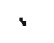

